\title{
Article
}

\section{Analysis of four PCR/SNaPshot multiplex assays analyzing 52 SNPforlD markers}

Goodwin, William H and Alimat, Sharizah

Available at http://clok.uclan.ac.uk/17102/

Goodwin, William H ORCID: 0000-0002-3632-3552 and Alimat, Sharizah (2017) Analysis of four PCR/SNaPshot multiplex assays analyzing 52 SNPforlD markers. ELECTROPHORESIS, 38 (7). pp. 1007-1015. ISSN 0173-0835

It is advisable to refer to the publisher's version if you intend to cite from the work. http://dx.doi.org/10.1002/elps.201600383

For more information about UCLan's research in this area go to

http://www.uclan.ac.uk/researchgroups/ and search for < name of research Group>.

For information about Research generally at UCLan please go to http://www.uclan.ac.uk/research/

All outputs in CLoK are protected by Intellectual Property Rights law, including Copyright law. Copyright, IPR and Moral Rights for the works on this site are retained by the individual authors and/or other copyright owners. Terms and conditions for use of this material are defined in the policies page.

\section{CLoK}

Central Lancashire online Knowledge www.clok.uclan.ac.uk

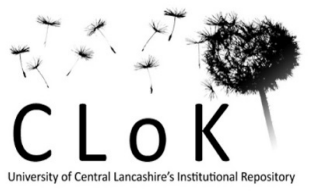




\title{
Analysis of four PCR/SNaPshot multiplex assays analyzing 52 SNPforID markers
}

\begin{abstract}
The SNPforID consortium identified a panel of 52 SNPs forensic analysis that has been used by several laboratories worldwide. The original analysis of the 52 SNPs was based on a single multiplex reaction followed by two single-base-extension (SBE) reactions each of which was analyzed using capillary electrophoresis. The SBE assays were designed for high throughput genetic analyzers and were difficult to use on the single capillary ABI PRISM 310 Genetic Analyzer and the latest generation 3500 Genetic Analyzer, as sensitivity on the 310 was low and separation of products on the 3500 with POP-7 ${ }^{\mathrm{TM}}$ was poor. We have modified the original assay and split it into four multiplex reactions, each followed by an SBE assay. These multiplex assays were analyzed using polymer POP-4 ${ }^{\mathrm{TM}}$ on ABI 310 PRISM® and polymers POP-4 ${ }^{\mathrm{TM}}$, POP-6 ${ }^{\mathrm{TM}}$ and POP-7 ${ }^{\text {TM }}$ on the 3500 Genetic Analyzer. The assays were sensitive and reproducible with input DNA as low as 60 pg using both the ABI 310 and 3500. In addition, we found that POP-6 $6^{\mathrm{TM}}$ was most effective with the 3500 , based on the parameters that we assessed, achieving better separation of the small SBE products; this conflicted with the recommended use of POP-7TM by the instrument manufacturer. To support the use of the SNP panel in casework in Malaysia we have created an allele frequency database from 325 individuals, representing the major population groups within Malaysia. Population and forensic parameters were estimated for all populations and its efficacy evaluated using 51 forensic samples from challenging casework.
\end{abstract}




\section{$1 \quad$ Introduction}

While short tandem repeat (STR) analysis remains the primary tool in forensic genetics additional markers to analyze degraded DNA are desirable. A number of SNP panels have been evaluated for individual identification (IISNPS), including the SNPforID panel, which was developed by a European consortium [1]. In the original SNPforID study 52 SNPs were amplified in a single PCR followed by two single-base extension (SBE) reactions, using capillary electrophoresis (CE). The two SBE reactions contained 23 and 29 primers; the PCR products size ranged from 59 bp to 115 $\mathrm{bp}$, whilst the SBE products size ranged from 16 to $92 \mathrm{nt}[1]$.

The original system was developed using SNaPshot ${ }^{\circledR}$ Multiplex System to detect the SNPs on three genetic analyzers: $\mathrm{ABI} 310 \mathrm{PRISM}^{\circledR}, \mathrm{ABI} 3100 \mathrm{PRISM}^{\circledR}$ and $\mathrm{ABI} 3100 \mathrm{PRISM}^{\circledR}$ Avant, all with $36 \mathrm{~cm}$ capillary arrays and performance optimized polymer POP- $4^{\mathrm{TM}}$ (Applied Biosystems, USA). The reported sensitivity of the $A B I 310$ PRISM ${ }^{\circledR}$ was only $20 \%$ of the sensitivity of the ABI 3100 PRISM $^{\circledR}$, and therefore most of the development studies were carried out using $A B I 3100$ or $A B I 3100$ Avant PRISM ${ }^{\circledR}$ Genetic Analyzers. The system has subsequently been validated for use in ISO 17025 accredited laboratories [2], but is not without challenges, in particular peak imbalances between alleles $[1,3]$. These challenges have been addressed by developing alternative techniques, such as oligo-ligation [3] and more recently systems developed for next generation sequencing have gained attention in the forensic community as a technology that allows the typing of large SNP arrays [4-6]. Modifications of the multiplexes have also been reported, splitting the PCR into two or more separate amplification reactions, which helped to increase sensitivity, allowing the $A B I 310$ platform to be used, and facilitating the interpretation of SNaPshot ${ }^{\oplus}$ data $[7,8]$.

The SNP markers from the SNPforID 52plex were selected for evaluation as a supplementary genetic marker for casework in Malaysia using capillary electrophoresis platforms. During the development the platforms available were the $A B I 310$ Prism $^{\circledR}$ and the 3500 Genetic Analyzer; the primary aim of the work was to redesign the multiplexes to facilitate interpretation using these platforms. In this study we describe the development of four 13-plex PCR/SNaPshot assays (designated as $13_{s t}, 13_{n d}, 13_{r d}$ and $13_{t h}$ ) and the analysis using polymer POP-4 ${ }^{\mathrm{TM}}$ with $\mathrm{ABI} 310$ and POP $-4^{\mathrm{TM}}$, POP $-6^{\mathrm{TM}}$ and POP $-7^{\mathrm{TM}}$ with a 3500 Genetic Analyzer. The reproducibility and sensitivity 
of the assays were assessed during this study and population data for the three major ethnic groups of Malaysia, Malay, Malaysian Chinese (M-Chinese) and Malaysian Indian (M-Indian), were generated as a reference source for casework. The efficacy of SNPs in challenging casework using the redesigned assays was also assessed.

\section{$2 \quad$ Materials and Methods}

\subsection{Sample, DNA extraction, purification and quantification}

For Malay, M-Chinese and M-Indian populations 325 samples were collected after gaining informed consent on FTA ${ }^{\oplus}$ Classic Card and purified using either phenol/chloroform/isoamyl alcohol or QIAamp ${ }^{\circledR}$ DNA Investigator Kit (Qiagen, UK) according to the manufacturer's protocol. DNA was quantified using Quantifler ${ }^{\mathrm{TM}}$ Human DNA Quantification kit (Applied Biosystems, UK) with a 7500 Real-Time PCR system (Applied Biosystems). The procedure was carried out according to the manufacturer's protocol, but with half volumes.

9947A and TaqMan ${ }^{\circledR}$ Control Genomic DNA (Applied Biosystems) were used as DNA controls throughout study.

\section{$2.2 \quad$ Multiplex SNPs assay set-up}

Several combinations of the PCR and SBE primers were evaluated before selecting the most robust combinations. Finally, four 13-plex assays were developed, named $13_{s t}, 13_{n d}, 13_{r d}$ and $13_{t h}$. All sequences and sizes of PCR/SBE primers were the same as previously described [1], except for 14 SBE primers that were modified to balance the designated assays. Each modification involved the addition or reduction of poly thymidine (poly $\mathrm{T}$ ) or poly cytosine (poly $\mathrm{C}$ ) to the $5^{\prime}$ end of the SBE primer. The new SBE length (bp) and the final combinations and concentrations of all primer pairs in each multiplexed (both PCR and SBE reactions) are presented in Table 1.

\subsection{Amplification and PCR Purification}

The total reaction volume of $15 \mu$ l comprised $1 X$ AmpliTaq Buffer II, 3.0 mM MgCl solution, 0.4 mM dNTPs, $2 U$ AmpliTaq ${ }^{\circledR}$ DNA Polymerase and $1 \mu$ I DNA sample (all the PCR components from 
Applied Biosystems). All other steps of PCR and purification reactions were performed as described previously [1].

\subsection{SBE reaction and products clean-up using SAP (USB, Affymetrix, USA)}

The SBE reactions were carried out using ABI Prism SNaPshot ${ }^{\oplus}$ Multiplex Kit (Applied Biosystems). The optimized SBE multiplex reactions contained $2.0 \mu \mathrm{l}$ of SNaPshot mix, $1.5 \mu \mathrm{l}$ of purified PCR product and $1 \mu \mathrm{l}$ of mixed SBE primers. The nuclease-free water was added to make up the total reaction volume to $5 \mu$ l. Thermal cycling conditions and SAP purification steps were as described previously [1].

\subsection{Capillary Electrophoresis with ABI 310 PRISM $^{\circledR}$ Genetic Analyzer}

$1 \mu \mathrm{l}$ of SAP- treated SBE products was diluted in $11 \mu \mathrm{l}$ of $\mathrm{Hi}^{-\mathrm{Di}^{\mathrm{TM}}}$ formamide and $0.4 \mu \mathrm{l} \mathrm{GeneScan}{ }^{\mathrm{TM}}$ 120-LIZ Internal Size Standard (Applied Biosystems). Samples were initially analyzed using an ABI 310 PRISM $^{\circledR}$ Genetic Analyzer with POP- $4^{\mathrm{TM}}$ polymer, $36 \mathrm{~cm}$ capillary array, injection time: $5 \mathrm{~s}$, injection voltage: $1.2 \mathrm{kV}$ and run time: $1800 \mathrm{~s}$.

\subsection{Concordance Study using $\mathbf{3 5 0 0}$ Genetic Analyzer}

20 control and population samples were re-analyzed using a 3500 Genetic Analyzer with different parameters: (i) POP-4 ${ }^{\mathrm{TM}}$ polymer, with $36 \mathrm{~cm}$ capillary array, injection time: $10 \mathrm{~s}$, injection voltage: 1.2 kV, run time: 2800 s, dye set: E5, application type: HID, run module: HID36_POP4, (ii) POP-6 ${ }^{\text {TM }}$ polymer, with $50 \mathrm{~cm}$ capillary array, injection time: $10 \mathrm{~s}$, injection voltage: $1.6 \mathrm{kV}$, run time: 2800 s, dye set: E5, application type: fragment, run module: fragmentAnalysis50_POP6, and (iii) POP$7^{\text {TM }}$ polymer, with $50 \mathrm{~cm}$ capillary array, injection time: $10 \mathrm{~s}$, injection voltage: $1.6 \mathrm{kV}$, run time: 2800 s, dye set: E5, application type: fragment, run module: fragmentAnalysis50_POP7.

\subsection{SNP typing with polymer POP-6 ${ }^{\mathrm{TM}}$ and ABI 3500 PRISM $^{\circledR}$ Genetic Analyzer}

The volume for each SBE multiplex assay was reduced to $1.7 \mu \mathrm{l}$ of SNaPshot mix, $1 \mu \mathrm{l}$ of purified PCR product and $1 \mu \mathrm{l}$ of mixed SBE primers, made to a final volume of $5 \mu \mathrm{l}$ with nuclease-free water. Following final optimization, all control DNA samples, with template amounts ranging from $0.01 \mathrm{ng}$ to $2.5 \mathrm{ng}$ (in triplicates) and population samples were analyzed with polymer POP- 
$6^{\mathrm{TM}}$ on a 3500 Genetic Analyzer. An example of the profiles generated from a sensitivity study are shown in Supplementary Figure 1.

\subsection{Data collection and evaluation}

SNaPshot data from the ABI 310 PRISM $^{\circledR}$ Genetic Analyzer were analyzed using GeneMapper ${ }^{\text {TM }}$ ID Software version 3.2; data collected from the 3500 PRISM $^{\circledR}$ Genetic Analyzer were analyzed using GeneMapper ${ }^{\circledR}$ ID-X version 1.2. For all analysis peak thresholds were set to a minimum of 120 RFU (blue), 60 RFU (green) and 30 RFU (yellow, red and orange). The acceptable peak height ratio for heterozygote allele calls was 3:1 (maximum) and a minimum of 5:1 peak height ratio (with a minimum peak height of 400 RFUs (blue), 200 RFUs (green) or 100 RFUs (yellow and red)) for homozygote alleles. These were based on the criteria previously described [1] and verified using commercial DNA 9947A and thirty full profiles generated on both the 310 and 3500.

\subsection{Analysis of population data}

FST values and the exact test for Hardy Weinberg equilibrium (HWE) and linkage equilibrium (LE) were carried out using Arlequin version 3.5 [9]. Forensic parameters were calculated using PowerStats version 1.2 [10]. Population attribution was estimated using Arlequin version 3.5 and Snipper version 2.5 [11]. 


\section{$3 \quad$ Results}

\subsection{Development and optimization of the assays}

Four sets of 13-plex PCR/SBE reactions were developed in this study; the organization of the markers and concentration of primers are shown in Table 1. Studies using ABI 310 demonstrated that multiplex assays were amplified effectively under the optimal conditions and parameters as detailed in Sections 2.3 to 2.5. The size and labeling of the SBE products was as expected and the profiling of a QC sample (9947A) was compared to an external reference and showed full concordance. Using DNA template amounts of $(0.01,0.02,0.03,0.06,0.13,0.25,0.5$ and 1.0$) \mathrm{ng}$ complete profiles were generated from all reactions that used $0.06 \mathrm{ng}$ or more template. An example of the $13_{\text {th }}$ assay is shown as Fig. $1 \mathrm{~A}$.

Profiles were generated from 325 population samples with input DNA as low as $0.1 \mathrm{ng}$ up to 500 ng. No locus drop-out or unusual peaks were observed. However, peak imbalances and baseline noise was observed in samples with that less than $0.06 \mathrm{ng}$ and higher than $30 \mathrm{ng}$ DNA.

\subsection{Analysis of 13-plex assays with different parameters using a 3500 Genetic Analyzer}

Initially, the SNPS genotyping of the same SAP-treated products from the previous internal validation study using $A B I 310$ was carried out using POP- $7^{\mathrm{TM}}$ with a $50 \mathrm{~cm}$ capillary array on a 3500, following the recommended manufacturer's protocol [12]. However, the resolution of the alleles was poor, especially for the SBE products below $60 \mathrm{nt}$; we carried out further analysis using POP $-4^{\mathrm{TM}}$ and POP-6 ${ }^{\mathrm{TM}}$. Results obtained are shown in Fig. 1, where the same samples of the $13_{\mathrm{th}^{-}}$ plex assay were run using different types of polymer. Peak heights were similar using all polymers (5000 to 7000 RFU) for all profiles when using the 3500, but each showed different allelic migration patterns, especially for SNP alleles below $60 \mathrm{nt}$. Samples analyzed using POP-6 ${ }^{\mathrm{TM}}$ on the 3500 showed the best separation (POP- $4^{\mathrm{TM}}$ was not tested with a $50 \mathrm{~cm}$ capillary). As the sensitivity of the 3500 was higher than the 310 the amount of reaction mixture could be reduced and comparable results, in terms of peak height, obtained (see Section 2.7). 
Fig. 2 shows an example of full SNP profile with designated 13-plex assays $\left(13_{s t}, 13_{n d}, 13_{r d}\right.$ and $\left.13_{t h}\right)$, obtained from $1 \mathrm{ng}$ of DNA sample using POP- $6^{\mathrm{TM}}$ with a 3500 Genetic Analyzer. All four 13plex assays were arranged as 4 panels per individual (52 autosomal SNP markers) for better visualization and easier interpretation.

\subsection{Population data}

Malaysia is multi-racial country with more than 70 identified ethnic groups. These are broadly classified into four main groups: Bumiputera, including Malay and indigenous groups; M-Chinese; M-Indians and others. In Malaysia it is standard practice to generate reference databases for Malay, M-Chinese and M-Indian populations before using new genetic markers in casework. In total, 325 samples were analyzed, 109 Malay and M-Indian and $107 \mathrm{M}$-Chinese, with the optimized assay using a 3500 Genetic Analyzer. Minimum allele frequencies were 0.079 in MChinese and 0.096 in Malay (both SNP marker 29) and 0.142 in M-Indian (at SNP marker 16); no value was below the minimal allele frequency typically used in casework, i.e. $5 / 2 \mathrm{~N}(0.023)$. The allele frequencies are shown in Supplementary Table 1 along with allele frequencies from other populations for comparison [13]. The combined match probabilities for the 52 SNPs were: Malay $3.9654 \mathrm{e}^{-19}, \mathrm{M}$-Chinese $5.3964 \mathrm{e}^{-18}$, and M-Indian $1.7459 \mathrm{e}^{-19}$ (Supplementary Table 2).

The exact test for departures from Hardy Weinberg equilibrium detected significant differences, after Bonferroni correction, at one locus in Malays (SNP code 26), two loci in M-Chinese (SNP codes 46 and 54) and 5 loci in M-Indians (SNP codes 12, 21, 36, 38, and 54) (Supplementary Table 3). The exact test for linkage equilibrium identified linkage $(p=<0.05)$ at 73 pairs of loci in Malays, 55 pairs in M-Chinese and 80 pairs in M-Indians; however, after Bonferroni correction $(p=$ $<0.0000377$ ) only one pair of loci was significant, this was between SNP 3 (chromosome 3) and 53 (chromosome 22) in the Malay population.

Between Malay and M-Chinese the $\mathrm{F}_{\mathrm{ST}}$ was estimated at 0.00711, Malay and M-Indian 0.03460 and M-Chinese and M-Indian 0.04133. While the IISNP marker panels have not developed for differentiating between populations there were clearly differences between the allele frequencies in the East Asian populations compared to the M-Indian population. The data were examined with both Arlequin and Snipper to assess the power of the 52 SNPs to classify individual 
samples into the correct population (Table 2 and Supplementary Figure 2). Following cross validation a high proportion of $\mathrm{M}$-Indian samples, $92 \%$, were correctly classified; the majority of Malay and $\mathrm{M}$-Chinese samples are also correctly classified, but over $25 \%$ of Malays were classified as M-Chinese and vica versa.

\subsection{Application to casework}

A small number of samples, 51 samples in total from 10 different cases, which had been processed with varying degrees of success were re-extracted and amplified using the PowerPlex ${ }^{\circledR}$ 16 System (PP16) and the SNP panels. Of the 51 samples, following re-extraction, 19 gave a full profile with PP16, all of these profiles gave a full 52 SNP profile. Nine of the samples gave partial STR profiles ranging from 13 loci to 7 loci, of these full 52 SNP profiles were possible for 7 of the samples and partial profiles (26 and 33 SNPs) for the remaining 2 . Of the 23 samples that gave no STR profile 10 could not be profiled at any SNP, 10 could be profiled at all 52 SNPs and 3 gave partial profiles with between 39 and 50 SNPs (Supplementary Table 4)[14]. The match probabilities of the full profiles, when applying an Fst value of 0.01 , ranged from $1 \mathrm{e}^{-18}$ to $2 \mathrm{e}^{-23}$; partial profiles ranged from $2.8 \mathrm{e}^{-10}$ to $5.1 \mathrm{e}^{-19}$ (Supplementary Table 5). Some caution has to be exercised when interpreting these results as reference samples were not available for comparison (i.e. from the donor), so the accuracy of the profiles could not be verified. However, apart from that partial nature of some profiles, they were otherwise judged to be of good quality, meeting the criteria detailed in Section 2.8, and identical profiles, apart from some locus dropout, were obtained from at least two different pieces of evidence from each case.

The SNP assays were also used to process 11 paternity cases that had been examined previously using STR analysis with PP16. These comprised four duos, with child and alleged father, six trios, and one case with mother, three children and alleged father: one case had a single mutation between the child and father and a case had two mutations between the child and the alleged father (the cases with mutations had been examined to exclude avuncular relationships). For the nine children tested with both a mother and father the combined paternity index (CPI) for all of the cases were all in excess of $2 \mathrm{e}^{6}$ using the 52 SNPs, which translated to a probability of paternity of $99.99995 \%$ when using a prior probability of 0.5 (Supplementary Table 6). The CPI for the four 
children tested with only the father for reference was lower, with three of the cases below 1000, and one below 100; the 15 STR markers were more informative in the duo cases.

\section{Discussion}

The SNPforID panel is one of the IISNP panels adopted by the forensic community. Other IISNP panels have also been developed, such as a 92 IISNP panel, 86 of which did not show strong linkage and is commonly referred to as the KiddLab panel [15], a 21-plex [16] and an 18-plex specifically designed to be more robust when amplifying degraded DNA [17]. The KiddLab panel and SNPforID 52-plex have formed the basis for many of the commercially developed platforms, such as the Genoplex typing system from Applied Biosystems, that utilized 49 of the 52 SNPs from the SNPforID panel [3], the iPLEX ${ }^{\circledR}$ Sample ID Plus Panel from Sequenom that utilized 47 of the 52 SNPs from the SNPforID panel [18], the AmpliSeq ${ }^{\mathrm{TM}}$ Identity panel (Applied Biosystems) and ForenSeq $^{\mathrm{TM}}$ Signature Prep Kit (Illumina, USA) that incorporate SNPs from both the SNPforID panel and KiddLab panel $[5,6,19]$. When selecting SNPs for forensic analysis the SNPforID and KiddLab panels have been developed to ensure that the associated forensic parameters, such as power of discrimination and lack of genetic linkage in multiple tested populations, make them robust genetic markers.

The approach taken in this study to increasing the sensitivity of the assay was to split the initial PCR and subsequent SBE reactions into four separate reactions. This has the advantage of making the assays easier to balance and also separate out the loci, reducing the number of loci amplified also increased the sensitivity, with only $60 \mathrm{pg}$ of DNA needed to generate balanced profiles; this compares to $>200 \mathrm{pg}$ needed when all amplicons were amplified on a single reaction [1]. The increased sensitivity is commonly seen when amplifying fewer amplicons, for example the IrisPlex, which co-amplified just 6 loci needed only 31 pg of DNA [20]. The disadvantage of splitting the assay is that four separate reactions are required to generate a full profile; however, in the application to casework, the SNPs would be typically used as a supplementary tool and all four panels may not be needed in order to reach an acceptable likelihood threshold (or exclusion). An alternative approach to increasing the sensitivity of the analysis used a PCR mix 
optimized for STR analysis and increased SBE cycles, which enabled a 49-plex reaction to be stably amplified from only 50 pg DNA [21]. Massive parallel sequencing approaches have been also been reported to increase the sensitivity of assays to as little as $31 \mathrm{pg}$ [6], but range to $0.5 \mathrm{pg}$ to $1 \mathrm{pg}$ of input DNA $[4,5,22]$.

Best practice in forensic genetics requires the generation of appropriate population reference databases so that the use of approximate/regional populations is not necessary. It was therefore imperative to generate reference databases for the three main population groups in Malaysia, i.e. Malay, M-Chinese and M-Indian. Five loci were shown not to be in Hardy Weinberg equilibrium in the M-Indian population, one loci in Malays, and two in M-Chinese; this could be due to sampling effects or reflect a degree of selection or inbreeding within the tested populations. It could also be due to technical issues, in particular primer binding site mutations, that could result in an excess of homozygotes. Sequencing of primer sites in the target populations would identify potential problems and allow alternative/additional primers to be developed, but was beyond the scope of this project.

Typical forensic parameters were, as expected, very similar to previously typed populations [1, 23], in addition there was very little evidence for linkage at the population level. FST between Malay and M-Chinese was low, which was expected given their well-characterized genetic relationship [24]; between the M-Indian and M-Chinese/Malay the $\mathrm{F}_{S T}$ values were above 0.003 . While the identification of bio-geographical origin was not the aim of this research the apparent differences in allele frequencies between the Indian population and Malay/M-Chinese in particular and could be exploited for this purpose. Assessment using both Arlequin and Snipper correctly predicted the origin of most M-Indian samples, whereas Malay and M-Chinese were more challenging to separate. The predictive power of analysis could well be improved by utilizing assays that have been specifically designed for this purpose, such as the SNPforID 34plex, with SNPS selected in part on the different allele frequencies between populations [25] and the KiddLab ancestry panel $[26,27]$. However, the implementation of this type of analysis is not currently undertaken in Malaysia and no decision has been made on whether it will be used; its implementation would be especially sensitive as it could be seen to discriminate against one minority population. 
A selection of problematic casework samples was processed as part of this study. The results were promising, with approximately $50 \%$ of samples that gave no results using STR analysis with PP16 giving full or highly informative SNP profiles. The increased success rate was in part down to the increase sensitivity of the SNP assay in comparison to the PP16; this was apparent when small amplicons in the PP16 profile were not detected whereas larger amplicons in the SNP profile were successfully amplified. In some cases DNA degradation made it challenging to obtain full profiles, especially using STRs and the short amplicon sizes in the SNP assay facilitated profiling of the highly degraded samples. The sensitivity of the SNP assay could potentially be further enhanced by applying the amplification and SBE protocols described by Borsting et al (2013)[21]. Similarly, the latest generation of STR kits, such as ESI (Promega), NGM (Applied Biosystems and DNA Investigator (Qiagen) [28-30] also have greater sensitivity than the PP16 and so may have yielded results in a greater proportion of the cases sampled in this study, although the STRs still have larger amplicons than the SNPs. The processing of the kinship cases provided resolution of all the cases where two parents were available, supporting the use of the SNP panel as a supplementary method in kinship analysis for the current STR-based systems [7, 31-35]. However, in deficient cases additional STR markers may be more productive as the paternity indexes generated from the duo cases was lower than with PP16. In conclusion, the SNPforID panel has been shown to be of potential value for forensic casework in Malaysia, providing increased sensitivity and capability to profile highly degraded samples; population reference databases are available should it be implemented in this format or using a massive parallel sequencing platform. 


\section{References}

[1] Sanchez, J. J., Phillips, C., Børsting, C., Balogh, K. et al. Electrophoresis 2006, 27, 1713-1724.

[2] Musgrave-Brown, E., Ballard, D., Balogh, K., Bender, K. et al. Forensic Sci. Int. Genet. 2007, 1, 186-190.

[3] Phillips, C., Fang, R., Ballard, D., Fondevila, M. et al. Forensic Sci. Int. Genet. 2007, 1, 180185.

[4] Daniel, R., Santos, C., Phillips, C., Fondevila, M. et al. Forensic Sci. Int. Genet. 2015, 14, 50-60.

[5] Churchill, J. D., Schmedes, S. E., King, J. L., Budowle, B. Forensic Sci. Int. Genet. 2016, 20, 20-

29.

[6] Elena, S., Alessandro, A., Ignazio, C., Sharon, W. et al. Forensic Sci. Int. Genet. 2016, 22, 25-

36.

[7] Schwark, T., Meyer, P., Harder, M., Modrow, J. -., Von Wurmb-Schwark, N. Transfus. Med. Hemotherapy 2012, 39, 187-193.

[8] Bulbul, O., Phillips, C., Argac, D., Shahzad, M. S. et al. Forensic Sci. Int. Genet. Suppl. Ser. 2009, 2, 129-130.

[9] Excoffier, L., Laval, G., Schneider, S. Evolutionary Bioinformatics Online 2005, 1, 47-50.

[10] Tereba, A. Profiles in DNA 1999, 3, 14-16. 
[11] Santos, C., Phillips, C., Gomez-Tato, A., Alvarez-Dios, J. et al., in: Goodwin, W. (Ed.), Forensic DNA Typing Protocols, New York, Springer 2016, pp. In Press.

[12] Applied Biosystems. Applied biosystems 3500/3500xL Genetic Analyzer User Guide, Foster City, CA, Applied Biosystems 2009.

[13] Amigo, J., Phillips, C., Lareu, M., Carracedo, Á. Int. J. Leg. Med. 2008, 122, 435-440.

[14] Alimat, S., Hadi, S., Goodwin, W. Forensic Sci. Int. Genet. Suppl. Ser. 2013, 4, e178-e179.

[15] Pakstis, A. J., Speed, W. C., Fang, R., Hyland, F. C. L. et al. Hum. Genet. 2010, 127, 315-324.

[16] Dixon, L. A., Murray, C. M., Archer, E. J., Dobbins, A. E. et al. Forensic Sci. Int. 2005, 154, 6277.

[17] Freire-Aradas, A., Fondevila, M., Kriegel, A. -., Phillips, C. et al. Forensic Sci. Int. Genet. $2012,6,341-349$.

[18] Johansen, P., Andersen, J. D., Børsting, C., Morling, N. Forensic Sci. Int. Genet. 2013, 7, 482487.

[19] Eduardoff, M., Santos, C., De La Puente, M., Gross, T. E. et al. Forensic Sci. Int. Genet. 2015, $17,110-121$.

[20] Walsh, S., Liu, F., Ballantyne, K. N., Van Oven, M. et al. Forensic Sci. Int. Genet. 2011, 5, 170180. 
[21] Børsting, C., Mogensen, H. S., Morling, N. Forensic Sci. Int. Genet. 2013, 7, 345-352.

[22] Børsting, C., Fordyce, S. L., Olofsson, J., Mogensen, H. S., Morling, N. Forensic Sci. Int. Genet. 2014, 12, 144-154.

[23] Santos, C., Phillips, C., Fondevila, M., Porras-Hurtado, L. et al. Forensic Sci. Int. Genet. 2011, 5, e25-e26.

[24] Abdulla, M. A., Ahmed, I., Assawamakin, A., Bhak, J. et al. Science 2009, 326, 1541-1545.

[25] Fondevila, M., Phillips, C., Santos, C., Freire Aradas, A. et al. Forensic Sci. Int. Genet. 2013, 7, 63-74.

[26] Kidd, J. R., Friedlaender, F. R., Speed, W. C., Pakstis, A. J. et al. Invest. Genet. 2011, 2.

[27] Kidd, K. K., Speed, W. C., Pakstis, A. J., Furtado, M. R. et al. Forensic Sci. Int. Genet. 2014, $10,23-32$.

[28] Poetsch, M., Bayer, K., Ergin, Z., Milbrath, M. et al. Int. J. Leg. Med. 2011, 125, 733-739.

[29] Pajnic, I. Z., Pogorelc, B. G., Balažic, J., Zupanc, T., Štefanic, B. Croat. Med. J. 2012, 53, 1723.

[30] Tucker, V. C., Hopwood, A. J., Sprecher, C. J., McLaren, R. S. et al. Forensic Sci. Int. Genet. $2011,5,436-448$.

[31] Børsting, C., Morling, N. Forensic Sci. Int. Genet. 2011, 5, 236-241. 
[32] Børsting, C., Mikkelsen, M., Morling, N. Transfus. Med. Hemotherapy 2012, 39, 195-201.

[33] Børsting, C., Morling, N. Transfusion 2012, 52, 425-430.

[34] Pontes, M. L., Fondevila, M., Laréu, M. V., Medeiros, R. Transfus. Med. Hemotherapy 2015, $42,385-388$.

[35] Phillips, C., Fondevila, M., García-Magariños, M., Rodriguez, A. et al. Forensic Sci. Int. Genet. 2008, 2, 198-204. 


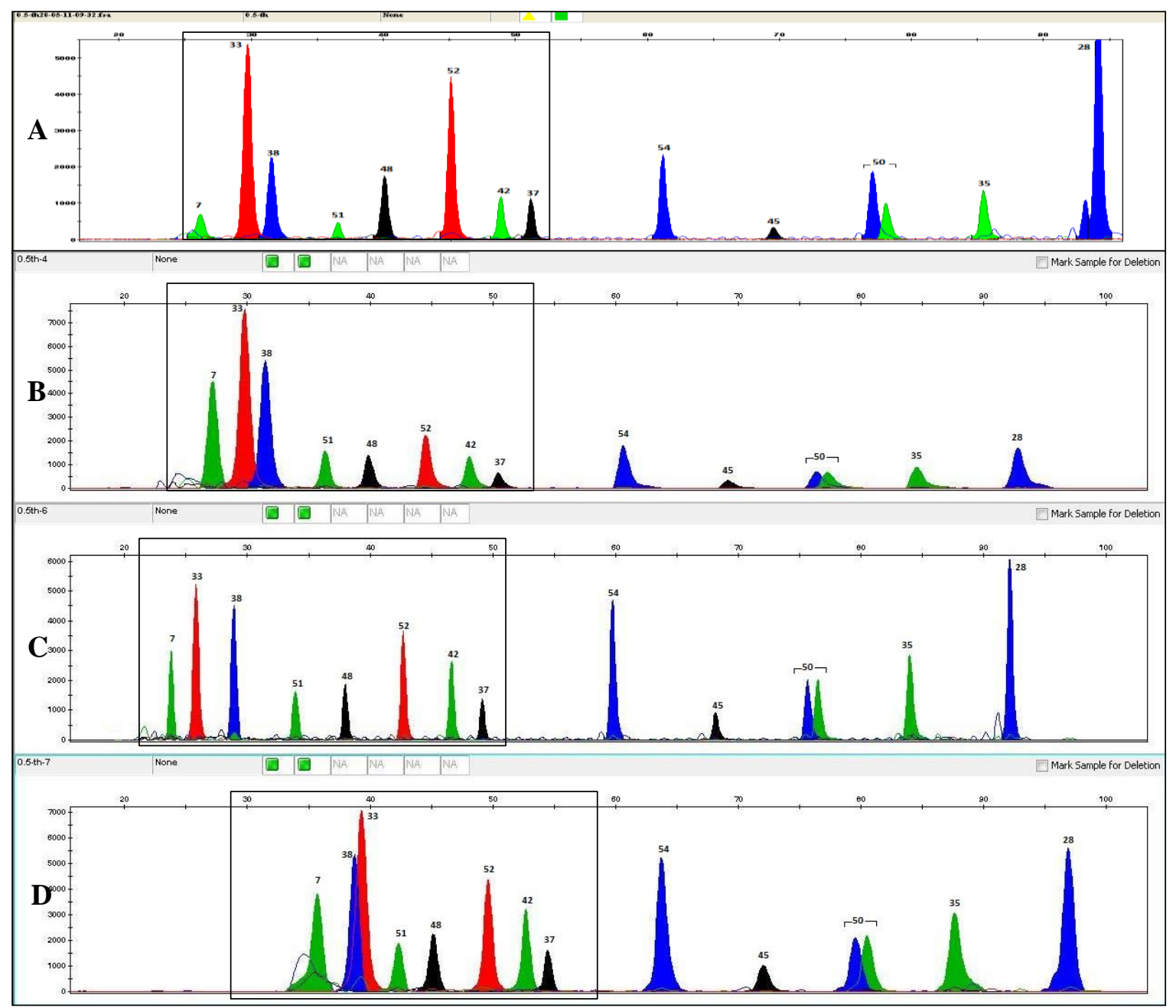

Figure 1 Comparison of SNaPshot profiles of $13_{\text {th }}$ multiplex assay using polymers; A) POP-4 $4^{\mathrm{TM}}$ on an ABI 310 PRISM $^{\circledR}$ Genetic Analyzer, B) POP-4 $4^{\mathrm{TM}}$, C) POP-6 ${ }^{\mathrm{TM}}$ and D) POP-7 $7^{\mathrm{TM}}$ on a 3500 Genetic Analyzer. Boxes show the most mobility-affected SNPs. 1 ng of DNA template was used. 


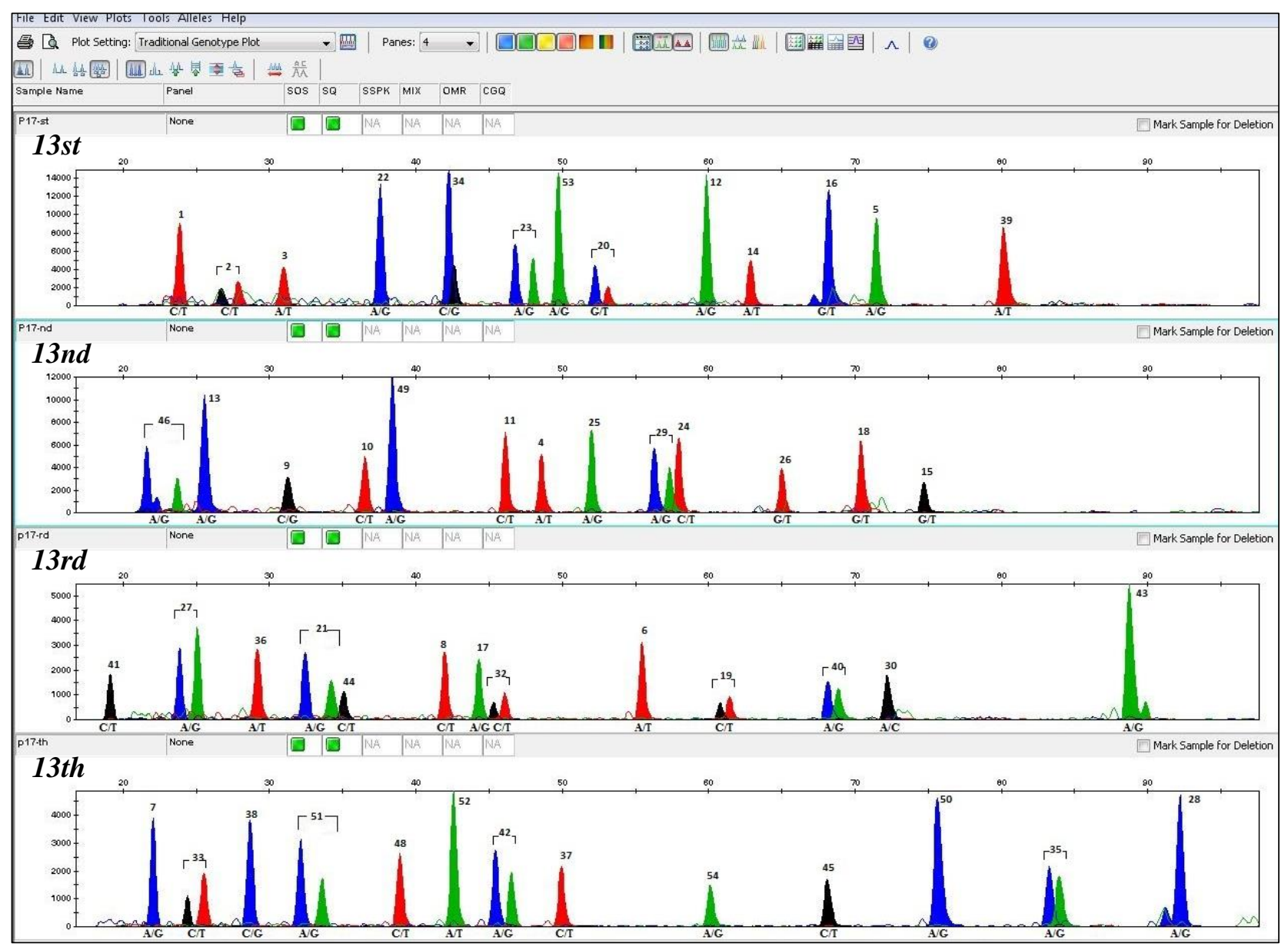

Figure 2 Full SNaPshot ${ }^{\circledR}$ profile of designated $13_{s t}, 13_{n d}, 13_{r d}$ and $13_{\text {th }}$ assays with $1 \mathrm{ng}$ template DNA using POP-6 ${ }^{\mathrm{TM}}$ with a 3500 Genetic Analyzer. 
Table 1: Four sets of 13-plex assay reactions developed in this study.

\begin{tabular}{|c|c|c|c|c|c|c|c|c|c|}
\hline \multicolumn{3}{|c|}{$\begin{array}{c}\text { Sanchez et al., } 2006 \\
\text { (Original SBE Multiplexes) } \\
\end{array}$} & \multirow{2}{*}{$\begin{array}{c}\text { Designated } \\
\text { multiplex } \\
\text { assays }\end{array}$} & \multirow[t]{2}{*}{$\begin{array}{l}\text { Marker } \\
\text { Code }\end{array}$} & \multirow[t]{2}{*}{$\begin{array}{l}\text { SNP } \\
\text { (rs\#) }\end{array}$} & \multicolumn{2}{|c|}{$\overline{\text { PCR }}$} & \multicolumn{2}{|c|}{$\begin{array}{l}\text { Single base extension } \\
\text { (SBE) }\end{array}$} \\
\hline $\begin{array}{c}\text { SBE } \\
\text { Multiplex }\end{array}$ & $\begin{array}{l}\text { Marker } \\
\text { Code }\end{array}$ & $\begin{array}{l}\text { SNP } \\
(\mathbf{r s \# )}\end{array}$ & & & & $\begin{array}{c}\text { Final primer } \\
\text { concentration } \\
(\mu \mathrm{M})\end{array}$ & $\begin{array}{l}\text { Amplicon } \\
\text { size (bp) }\end{array}$ & $\begin{array}{c}\text { Final primer } \\
\text { concentration } \\
(\mu \mathrm{M})\end{array}$ & $\begin{array}{c}\text { Amplicon } \\
\text { size (bp) }\end{array}$ \\
\hline \multirow{23}{*}{$\begin{array}{l}23 \text { SBE } \\
\text { Set }\end{array}$} & 1 & rs1490413 & \multirow{13}{*}{$13_{s t}$} & 1 & rs1490413 & 0.15 & 68 & 0.07 & 18 \\
\hline & 2 & rs876724 & & 2 & rs876724 & 0.1 & 83 & 0.1 & 24 \\
\hline & 3 & rs1357617 & & 3 & rs1357617 & 0.15 & 90 & 0.08 & 29 \\
\hline & 4 & rs2046361 & & 22 & rs733164* & 0.1 & 68 & 0.1 & $36(34)$ \\
\hline & 5 & rs717302 & & 34 & rs1979255 & 0.15 & 86 & 0.15 & 40 \\
\hline & 6 & rs1029047 & & 23 & rs826472* & 0.2 & 85 & 0.2 & $45(46)$ \\
\hline & 7 & rs917118 & & 53 & rs1028528 & 0.1 & 113 & 0.1 & 48 \\
\hline & 8 & rs763869 & & 20 & rs1031825 & 0.15 & 98 & 0.2 & 50 \\
\hline & 9 & rs1015250 & & 12 & rs2107612 & 0.15 & 93 & 0.3 & 58 \\
\hline & 10 & rs735155 & & 14 & rs1454361 & 0.1 & 73 & 0.15 & 62 \\
\hline & 11 & rs901398 & & 16 & rs729172* & 0.1 & 60 & 0.2 & $68(70)$ \\
\hline & 12 & rs2107612 & & 5 & rs717302* & 0.15 & 86 & 0.3 & $70(74)$ \\
\hline & 13 & rs1886510 & & 39 & rs354439 & 0.1 & 93 & 0.2 & 80 \\
\hline & 14 & rs1454361 & \multirow{13}{*}{$13_{n d}$} & 46 & rs1360288 & 0.1 & 103 & 0.07 & 16 \\
\hline & 15 & rs2016276 & & 13 & rs $1886510^{*}$ & 0.1 & 86 & 0.06 & $26(25)$ \\
\hline & 16 & rs729172 & & 9 & rs $1015250^{*}$ & 0.1 & 95 & 0.15 & $30(29)$ \\
\hline & 17 & rs740910 & & 10 & rs 735155 & 0.15 & 100 & 0.15 & 34 \\
\hline & 18 & rs1493232 & & 49 & rs1005533 & 0.1 & 107 & 0.1 & 36 \\
\hline & 19 & rs719366 & & 11 & rs901398* & 0.15 & 70 & 0.1 & $44(46)$ \\
\hline & 20 & rs1031825 & & 4 & rs $2046361^{*}$ & 0.3 & 79 & 0.15 & $47(78)$ \\
\hline & 21 & rs722098 & & 25 & rs 873196 & 0.1 & 63 & 0.15 & 52 \\
\hline & 22 & rs733164 & & 29 & rs1024116 & 0.1 & 76 & 0.1 & 56 \\
\hline & 23 & rs 826472 & & 24 & rs 2831700 & 0.1 & 62 & 0.15 & 56 \\
\hline \multirow{29}{*}{$\begin{array}{l}29 \text { SBE } \\
\text { Set }\end{array}$} & 24 & rs2831700 & & 26 & rs1382387 & 0.13 & 69 & 0.1 & 64 \\
\hline & 25 & rs873196 & & 18 & rs $1493232 *$ & 0.1 & 59 & 0.2 & $68(66)$ \\
\hline & 26 & rs1382387 & & 15 & rs 2016276 & 0.15 & 90 & 0.3 & 80 \\
\hline & 27 & rs2111980 & \multirow{13}{*}{$13_{r d}$} & 41 & rs737681 & 0.1 & 96 & 0.07 & 16 \\
\hline & 28 & rs2056277 & & 27 & rs2111980 & 0.05 & 72 & 0.05 & 23 \\
\hline & 29 & rs1024116 & & 36 & rs2076848 & 0.1 & 89 & 0.08 & 27 \\
\hline & 30 & rs727811 & & 21 & rs722098* & 0.15 & 81 & 0.15 & $32(38)$ \\
\hline & 32 & rs1413212 & & 44 & rs914165 & 0.1 & 100 & 0.15 & 32 \\
\hline & 33 & rs938283 & & 8 & rs763869* & 0.15 & 100 & 0.2 & $40(42)$ \\
\hline & 34 & rs1979255 & & 17 & rs740910 & 0.1 & 87 & 0.15 & 42 \\
\hline & 35 & rs1463729 & & 32 & rs1413212 & 0.3 & 84 & 0.3 & 44 \\
\hline & 36 & rs2076848 & & 6 & rs1029047 & 0.25 & 100 & 0.4 & 54 \\
\hline & 37 & rs1355366 & & 19 & rs719366* & 0.2 & 105 & 0.2 & $60(58)$ \\
\hline & 38 & rs907100 & & 40 & rs2040411 & 0.1 & 94 & 0.1 & 68 \\
\hline & 39 & rs354439 & & 30 & rs727811 & 0.15 & 78 & 0.15 & 72 \\
\hline & 40 & rs2040411 & & 43 & rs 251934 & 0.15 & 98 & 0.2 & 88 \\
\hline & 41 & rs737681 & \multirow{13}{*}{$13_{t h}$} & 7 & rs917118* & 0.1 & 87 & 0.15 & $20(18)$ \\
\hline & 42 & rs2830795 & & 33 & rs938283 & 0.08 & 85 & 0.1 & 22 \\
\hline & 43 & rs251934 & & 38 & rs907100 & 0.15 & 91 & 0.15 & 27 \\
\hline & 44 & rs914165 & & 51 & rs891700* & 0.1 & 109 & 0.1 & $31(32)$ \\
\hline & 45 & rs10495407 & & 48 & rs964681 & 0.15 & 106 & 0.15 & 36 \\
\hline & 46 & rs1360288 & & 52 & rs1335873 & 0.15 & 110 & 0.1 & 40 \\
\hline & 48 & rs964681 & & 42 & rs2830795 & 0.1 & 97 & 0.15 & 44 \\
\hline & 49 & rs1005533 & & 37 & rs1355366 & 0.15 & 90 & 0.15 & 48 \\
\hline & 50 & rs8037429 & & 54 & rs1528460 & 0.15 & 115 & 0.15 & 60 \\
\hline & 51 & rs891700 & & 45 & rs 10495407 & 0.4 & 102 & 0.2 & 68 \\
\hline & 52 & rs1335873 & & 50 & rs 8037429 & 0.2 & 108 & 0.15 & 76 \\
\hline & 53 & rs 1028528 & & 35 & rs1463729 & 0.1 & 87 & 0.15 & 84 \\
\hline & 54 & rs1528460 & & 28 & rs2056277 & 0.07 & 73 & 0.1 & 92 \\
\hline
\end{tabular}

Note: * indicates modified SBE primers length. Number in brackets show the original SBE amplicon size [3]. 
Table 2 Ancestry predictions with A) Snipper, B) Arlequin and C) Snipper with cross validation.

\begin{tabular}{|c|c|c|c|c|c|c|c|c|c|}
\hline & A & B & C & $A$ & B & $C$ & A & B & C \\
\hline $\begin{array}{c}\text { Population of Malay } \\
\text { origin }\end{array}$ & $82.57 \%$ & $70.64 \%$ & $64.22 \%$ & $11.93 \%$ & $17.76 \%$ & $26.61 \%$ & $5.50 \%$ & $8.26 \%$ & $9.17 \%$ \\
\hline $\begin{array}{c}\text { Population of Chinese } \\
\text { origin }\end{array}$ & $13.08 \%$ & $21.10 \%$ & $28.04 \%$ & $84.11 \%$ & $81.31 \%$ & $68.22 \%$ & $2.8 \%$ & $2.75 \%$ & $3.74 \%$ \\
\hline $\begin{array}{c}\text { Population of Indian } \\
\text { origin }\end{array}$ & $0.00 \%$ & $8.26 \%$ & $2.75 \%$ & $2.75 \%$ & $0.93 \%$ & $4.59 \%$ & $97.25 \%$ & $88.99 \%$ & $92.66 \%$ \\
\hline
\end{tabular}




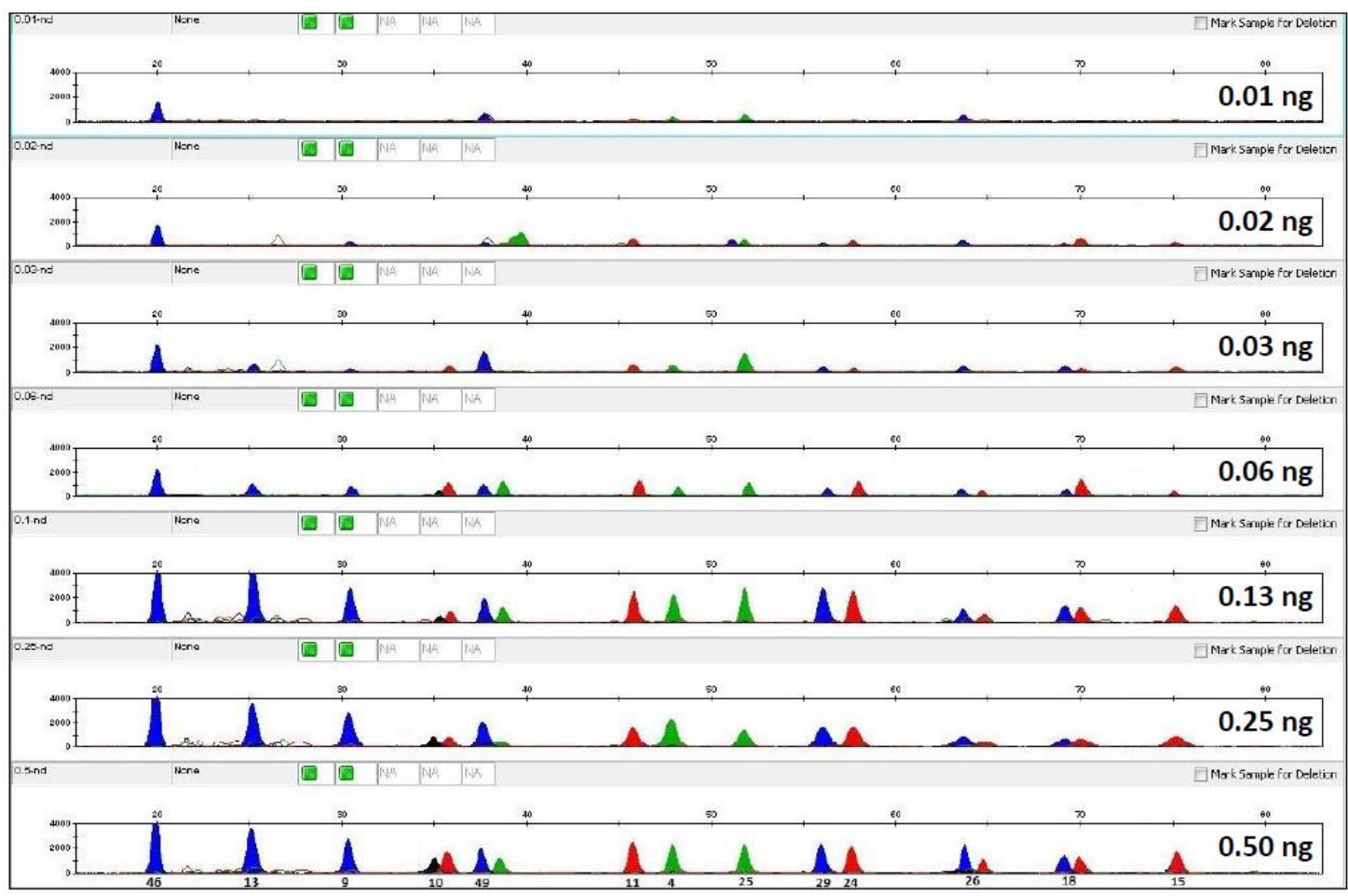

Supplementary Figure 1 13ndplex profiles with input template DNA from $0.01 \mathrm{ng}$ to $0.5 \mathrm{ng}$. 


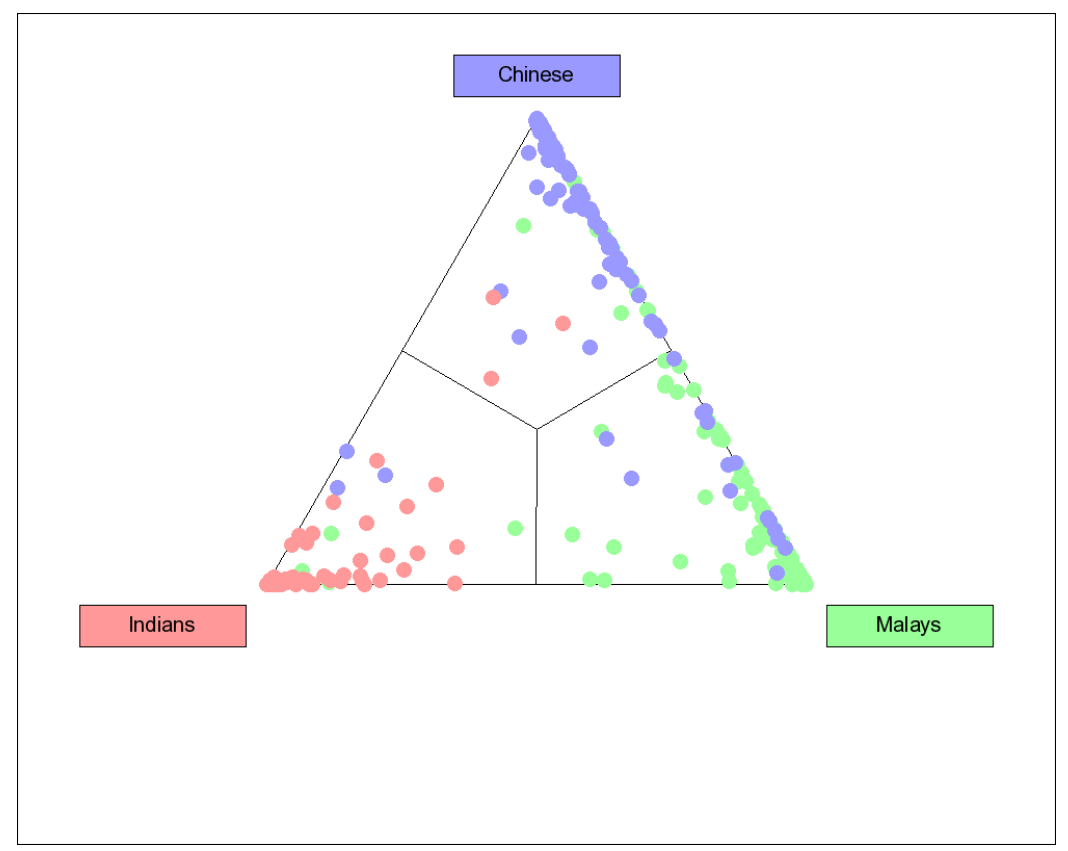

Supplementary Figure S2 Graphical representation of Snipper analysis. Each coloured dot represents an individual and the area that they are placed in represents the most likely population that they belong to based on their profile frequencies using each of the three reference allele frequency databases. 
Supplementary Table S1 Allele frequency data for Malaysia and neighboring regions

\begin{tabular}{|c|c|c|c|c|c|c|c|c|c|}
\hline \multicolumn{3}{|c|}{$\begin{array}{l}\text { Individual Identification SNPs } \\
\text { (IISNPs) }\end{array}$} & \multicolumn{7}{|c|}{ Allele frequencies } \\
\hline \multirow{2}{*}{$\begin{array}{l}\text { Marker } \\
\text { Code }\end{array}$} & \multirow[t]{2}{*}{ SNP } & \multirow[t]{2}{*}{ Allele } & \multicolumn{3}{|c|}{ Malaysia } & \multirow{2}{*}{$\begin{array}{l}\text { East Asia } \\
(\mathrm{N}=378)\end{array}$} & \multirow{2}{*}{$\begin{array}{l}\text { Central - } \\
\text { South } \\
\text { Asia ( } N= \\
\text { 234) }\end{array}$} & \multirow{2}{*}{$\begin{array}{l}\text { Oceania } \\
(N=28)\end{array}$} & \multirow{2}{*}{$\begin{array}{l}\text { Europe } \\
(\mathrm{N}= \\
1140)\end{array}$} \\
\hline & & & $\begin{array}{l}\text { Malay } \\
(\mathrm{N}=109)\end{array}$ & $\begin{array}{l}\text { M- } \\
\text { Chinese } \\
(\mathrm{N}=107)\end{array}$ & $\begin{array}{l}\text { M- } \\
\text { Indian } \\
(N=109)\end{array}$ & & & & \\
\hline \multirow{2}{*}{1} & \multirow{2}{*}{ rs1490413 } & C & 0.427 & 0.444 & 0.486 & 0.423 & 0.482 & 0.333 & 0.564 \\
\hline & & $\mathrm{T}$ & 0.573 & 0.556 & 0.514 & 0.577 & 0.518 & 0.667 & 0.436 \\
\hline \multirow{2}{*}{2} & \multirow{2}{*}{ rs876724 } & $\mathrm{C}$ & 0.647 & 0.682 & 0.674 & 0.564 & 0.724 & 0.981 & 0.685 \\
\hline & & $\mathrm{T}$ & 0.353 & 0.318 & 0.326 & 0.436 & 0.276 & 0.019 & 0.315 \\
\hline \multirow{2}{*}{3} & \multirow{2}{*}{ rs1357617 } & $A$ & 0.161 & 0.178 & 0.275 & 0.188 & 0.293 & 0.054 & 0.293 \\
\hline & & $T$ & 0.839 & 0.822 & 0.725 & 0.812 & 0.707 & 0.946 & 0.707 \\
\hline \multirow{2}{*}{4} & \multirow{2}{*}{ rs2046361 } & $A$ & 0.454 & 0.449 & 0.385 & 0.417 & 0.432 & 0.593 & 0.350 \\
\hline & & $\mathrm{T}$ & 0.346 & 0.551 & 0.615 & 0.583 & 0.568 & 0.407 & 0.650 \\
\hline \multirow{2}{*}{5} & \multirow{2}{*}{ rs717302 } & A & 0.734 & 0.855 & 0.601 & 0.848 & 0.625 & 0.696 & 0.503 \\
\hline & & G & 0.266 & 0.145 & 0.399 & 0.152 & 0.375 & 0.304 & 0.497 \\
\hline \multirow{2}{*}{6} & \multirow{2}{*}{ rs1029047 } & $A$ & 0.339 & 0.290 & 0.495 & 0.357 & 0.370 & 0.240 & 0.396 \\
\hline & & $T$ & 0.661 & 0.710 & 0.505 & 0.643 & 0.630 & 0.760 & 0.604 \\
\hline \multirow{2}{*}{7} & \multirow{2}{*}{ rs917118 } & $A$ & 0.225 & 0.285 & 0.413 & 0.267 & 0.448 & 0.232 & 0.283 \\
\hline & & G & 0.775 & 0.715 & 0.587 & 0.733 & 0.552 & 0.768 & 0.717 \\
\hline \multirow{2}{*}{8} & \multirow{2}{*}{ rs763869 } & $\mathrm{C}$ & 0.431 & 0.421 & 0.216 & 0.346 & 0.287 & 0.429 & 0.486 \\
\hline & & $\mathrm{T}$ & 0.569 & 0.579 & 0.784 & 0.654 & 0.713 & 0.571 & 0.514 \\
\hline \multirow{2}{*}{9} & \multirow{2}{*}{ rs1015250 } & C & 0.573 & 0.491 & 0.596 & 0.535 & 0.716 & 0.179 & 0.786 \\
\hline & & G & 0.427 & 0.509 & 0.404 & 0.465 & 0.284 & 0.821 & 0.214 \\
\hline 10 & $m_{-1}$ & C & 0.179 & 0.126 & 0.339 & 0.190 & 0.393 & 0.643 & 0.536 \\
\hline 10 & rS/35153 & $\mathrm{T}$ & 0.821 & 0.874 & 0.661 & 0.810 & 0.607 & 0.357 & 0.464 \\
\hline 11 & 政 & C & 0.257 & 0.294 & 0.335 & 0.265 & 0.274 & 0.214 & 0.326 \\
\hline 11 & rS901398 & $\mathrm{T}$ & 0.743 & 0.706 & 0.665 & 0.735 & 0.726 & 0.786 & 0.674 \\
\hline 17 & . & $A$ & 0.706 & 0.738 & 0.500 & 0.871 & 0.728 & 0.411 & 0.673 \\
\hline 12 & 132107012 & G & 0.294 & 0.262 & 0.500 & 0.129 & 0.272 & 0.589 & 0.327 \\
\hline $10+2$ & 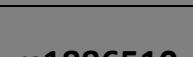 & $A$ & 0.142 & 0.159 & 0.271 & 0.117 & 0.209 & 0.161 & 0.436 \\
\hline 10 & 131000010 & G & 0.858 & 0.841 & 0.729 & 0.869 & 0.700 & 0.804 & 0.505 \\
\hline 1 & 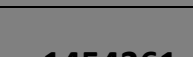 & $A$ & 0.564 & 0.570 & 0.615 & 0.492 & 0.476 & 0.143 & 0.531 \\
\hline 14 & rS1454361 & $\mathrm{T}$ & 0.436 & 0.430 & 0.385 & 0.508 & 0.524 & 0.857 & 0.469 \\
\hline 15 & rs2016276 & C & 0.349 & 0.350 & 0.261 & 0.377 & 0.214 & 0.054 & 0.231 \\
\hline
\end{tabular}




\begin{tabular}{|c|c|c|c|c|c|c|c|c|c|}
\hline & & $T$ & 0.651 & 0.650 & 0.739 & 0.623 & 0.786 & 0.946 & 0.769 \\
\hline \multirow{2}{*}{16} & \multirow{2}{*}{ rs729172 } & $\mathrm{G}$ & 0.844 & 0.860 & 0.858 & 0.836 & 0.726 & 0.946 & 0.598 \\
\hline & & $T$ & 0.156 & 0.140 & 0.142 & 0.164 & 0.274 & 0.054 & 0.402 \\
\hline \multirow{2}{*}{17} & \multirow{2}{*}{ rs740910 } & $A$ & 0.867 & 0.916 & 0.839 & 0.922 & 0.738 & 0.815 & 0.702 \\
\hline & & G & 0.133 & 0.084 & 0.161 & 0.078 & 0.262 & 0.185 & 0.298 \\
\hline \multirow{2}{*}{18} & \multirow{2}{*}{ rs1493232 } & $\mathrm{G}$ & 0.601 & 0.631 & 0.390 & 0.511 & 0.242 & 0.714 & 0.336 \\
\hline & & $T$ & 0.399 & 0.369 & 0.610 & 0.489 & 0.758 & 0.286 & 0.664 \\
\hline \multirow{2}{*}{19} & \multirow{2}{*}{ rs719366 } & $C$ & 0.335 & 0.215 & 0.312 & 0.231 & 0.377 & 0.778 & 0.373 \\
\hline & & $\mathrm{T}$ & 0.665 & 0.785 & 0.688 & 0.769 & 0.623 & 0.222 & 0.627 \\
\hline \multirow{2}{*}{20} & \multirow{2}{*}{ rs1031825 } & G & 0.463 & 0.486 & 0.546 & 0.568 & 0.577 & 0.714 & 0.731 \\
\hline & & $T$ & 0.537 & 0.514 & 0.454 & 0.432 & 0.423 & 0.286 & 0.269 \\
\hline \multirow{2}{*}{21} & \multirow{2}{*}{ rs722098 } & $A$ & 0.583 & 0.486 & 0.555 & 0.446 & 0.680 & 0.500 & 0.782 \\
\hline & & G & 0.417 & 0.514 & 0.445 & 0.554 & 0.320 & 0.500 & 0.218 \\
\hline \multirow{2}{*}{22} & \multirow{2}{*}{ rs733164 } & $A$ & 0.280 & 0.164 & 0.183 & 0.145 & 0.252 & 0.463 & 0.296 \\
\hline & & G & 0.720 & 0.836 & 0.817 & 0.855 & 0.748 & 0.537 & 0.704 \\
\hline \multirow{2}{*}{23} & \multirow{2}{*}{ rs826472 } & $A$ & 0.202 & 0.121 & 0.390 & 0.174 & 0.312 & 0.648 & 0.376 \\
\hline & & G & 0.798 & 0.879 & 0.610 & 0.826 & 0.688 & 0.352 & 0.624 \\
\hline \multirow{2}{*}{24} & \multirow{2}{*}{ rs2831700 } & C & 0.427 & 0.542 & 0.225 & 0.493 & 0.335 & 0.519 & 0.408 \\
\hline & & $T$ & 0.573 & 0.458 & 0.775 & 0.507 & 0.665 & 0.481 & 0.592 \\
\hline \multirow{2}{*}{25} & \multirow{2}{*}{ rs873196 } & $A$ & 0.839 & 0.911 & 0.812 & 0.864 & 0.703 & 0.679 & 0.599 \\
\hline & & G & 0.161 & 0.089 & 0.188 & 0.136 & 0.297 & 0.321 & 0.401 \\
\hline \multirow{2}{*}{26} & \multirow{2}{*}{ rs1382387 } & G & 0.413 & 0.393 & 0.408 & 0.304 & 0.293 & 0.185 & 0.319 \\
\hline & & $T$ & 0.587 & 0.607 & 0.592 & 0.696 & 0.707 & 0.815 & 0.681 \\
\hline \multirow{2}{*}{27} & \multirow{2}{*}{ rs2111980 } & $A$ & 0.610 & 0.603 & 0.509 & 0.619 & 0.491 & 0.648 & 0.456 \\
\hline & & G & 0.390 & 0.397 & 0.491 & 0.381 & 0.509 & 0.352 & 0.544 \\
\hline \multirow{2}{*}{28} & \multirow{2}{*}{ rs2056277 } & $A$ & 0.170 & 0.121 & 0.206 & 0.133 & 0.167 & 0.056 & 0.259 \\
\hline & & G & 0.830 & 0.879 & 0.794 & 0.867 & 0.833 & 0.944 & 0.741 \\
\hline \multirow{2}{*}{29} & \multirow{2}{*}{ rs1024116 } & $A$ & 0.096 & 0.079 & 0.284 & 0.121 & 0.412 & 0.500 & 0.573 \\
\hline & & G & 0.904 & 0.921 & 0.716 & 0.879 & 0.588 & 0.500 & 0.427 \\
\hline & & $A$ & 0.541 & 0.640 & 0.674 & 0.688 & 0.513 & 0.661 & 0.552 \\
\hline & & C & 0.459 & 0.360 & 0.326 & 0.312 & 0.487 & 0.339 & 0.448 \\
\hline 32 & rs1413212 & $C$ & 0.422 & 0.341 & 0.390 & 0.545 & 0.656 & 0.574 & 0.697 \\
\hline
\end{tabular}




\begin{tabular}{|c|c|c|c|c|c|c|c|c|c|}
\hline & & $\mathrm{T}$ & 0.578 & 0.659 & 0.610 & 0.455 & 0.344 & 0.426 & 0.303 \\
\hline \multirow{2}{*}{33} & \multirow{2}{*}{ rs938283 } & C & 0.284 & 0.150 & 0.161 & 0.150 & 0.103 & 0.019 & 0.169 \\
\hline & & $\mathrm{T}$ & 0.716 & 0.850 & 0.839 & 0.850 & 0.897 & 0.981 & 0.831 \\
\hline \multirow{2}{*}{34} & \multirow{2}{*}{ rs1979255 } & $C$ & 0.459 & 0.444 & 0.372 & 0.436 & 0.435 & 0.268 & 0.339 \\
\hline & & G & 0.541 & 0.556 & 0.628 & 0.564 & 0.565 & 0.732 & 0.661 \\
\hline \multirow{2}{*}{35} & \multirow{2}{*}{ rs1463729 } & $A$ & 0.495 & 0.533 & 0.454 & 0.449 & 0.507 & 0.058 & 0.556 \\
\hline & & G & 0.505 & 0.467 & 0.546 & 0.551 & 0.493 & 0.942 & 0.444 \\
\hline \multirow{2}{*}{36} & \multirow{2}{*}{ rs2076848 } & $A$ & 0.252 & 0.322 & 0.436 & 0.340 & 0.446 & 0.286 & 0.441 \\
\hline & & $\mathrm{T}$ & 0.748 & 0.678 & 0.564 & 0.660 & 0.554 & 0.714 & 0.559 \\
\hline \multirow{2}{*}{37} & \multirow{2}{*}{ rs1355366 } & C & 0.330 & 0.164 & 0.518 & 0.157 & 0.473 & 0.096 & 0.421 \\
\hline & & $\mathrm{T}$ & 0.670 & 0.836 & 0.482 & 0.843 & 0.527 & 0.904 & 0.579 \\
\hline \multirow{2}{*}{38} & \multirow{2}{*}{ rs907100 } & $\mathrm{C}$ & 0.468 & 0.533 & 0.463 & 0.550 & 0.550 & 0.786 & 0.606 \\
\hline & & G & 0.532 & 0.467 & 0.537 & 0.450 & 0.450 & 0.214 & 0.394 \\
\hline \multirow{2}{*}{39} & \multirow{2}{*}{ rs354439 } & $A$ & 0.408 & 0.421 & 0.569 & 0.431 & 0.638 & 0.875 & 0.418 \\
\hline & & $\mathrm{T}$ & 0.592 & 0.579 & 0.431 & 0.569 & 0.362 & 0.125 & 0.582 \\
\hline \multirow{2}{*}{40} & \multirow{2}{*}{ rs2040411 } & $A$ & 0.326 & 0.332 & 0.472 & 0.271 & 0.461 & 0.750 & 0.629 \\
\hline & & G & 0.674 & 0.668 & 0.528 & 0.729 & 0.539 & 0.250 & 0.371 \\
\hline \multirow{2}{*}{41} & \multirow{2}{*}{ rs737681 } & $C$ & 0.835 & 0.864 & 0.606 & 0.827 & 0.651 & 0.982 & 0.594 \\
\hline & & $\mathrm{T}$ & 0.165 & 0.136 & 0.394 & 0.173 & 0.349 & 0.018 & 0.406 \\
\hline \multirow{2}{*}{42} & \multirow{2}{*}{ rs2830795 } & $A$ & 0.399 & 0.537 & 0.706 & 0.516 & 0.770 & 0.821 & 0.709 \\
\hline & & G & 0.601 & 0.463 & 0.294 & 0.484 & 0.230 & 0.179 & 0.291 \\
\hline \multirow{2}{*}{43} & \multirow{2}{*}{ rs251934 } & $A$ & 0.867 & 0.888 & 0.688 & 0.875 & 0.758 & 0.696 & 0.614 \\
\hline & & G & 0.133 & 0.112 & 0.312 & 0.125 & 0.242 & 0.304 & 0.386 \\
\hline \multirow{2}{*}{44} & \multirow{2}{*}{ rs914165 } & C & 0.706 & 0.640 & 0.578 & 0.689 & 0.571 & 0.286 & 0.604 \\
\hline & & $\mathrm{T}$ & 0.294 & 0.360 & 0.422 & 0.311 & 0.429 & 0.714 & 0.396 \\
\hline \multirow{2}{*}{45} & \multirow{2}{*}{ rs10495407 } & $\mathrm{C}$ & 0.720 & 0.696 & 0.844 & 0.671 & 0.740 & 0.978 & 0.643 \\
\hline & & $\mathrm{T}$ & 0.280 & 0.304 & 0.156 & 0.329 & 0.260 & 0.022 & 0.357 \\
\hline 46 & rs1360288 & $A$ & 0.220 & 0.350 & 0.486 & 0.347 & 0.373 & 0.074 & 0.335 \\
\hline
\end{tabular}




\begin{tabular}{|c|c|c|c|c|c|c|c|c|c|}
\hline & & G & 0.780 & 0.650 & 0.514 & 0.653 & 0.627 & 0.926 & 0.665 \\
\hline \multirow{2}{*}{48} & \multirow{2}{*}{ rs964681 } & C & 0.335 & 0.360 & 0.436 & 0.298 & 0.423 & 0.375 & 0.417 \\
\hline & & $\mathrm{T}$ & 0.665 & 0.640 & 0.564 & 0.702 & 0.577 & 0.625 & 0.583 \\
\hline \multirow{2}{*}{49} & \multirow{2}{*}{ rs1005533 } & $A$ & 0.197 & 0.290 & 0.335 & 0.332 & 0.399 & 0.519 & 0.536 \\
\hline & & G & 0.803 & 0.710 & 0.665 & 0.668 & 0.601 & 0.481 & 0.464 \\
\hline \multirow{2}{*}{50} & \multirow{2}{*}{ rs8037429 } & $A$ & 0.422 & 0.374 & 0.390 & 0.456 & 0.543 & 0.583 & 0.516 \\
\hline & & G & 0.578 & 0.626 & 0.610 & 0.544 & 0.457 & 0.417 & 0.484 \\
\hline \multirow{2}{*}{51} & \multirow{2}{*}{ rs891700 } & $A$ & 0.472 & 0.458 & 0.422 & 0.504 & 0.417 & 0.357 & 0.475 \\
\hline & & G & 0.528 & 0.542 & 0.578 & 0.496 & 0.583 & 0.643 & 0.525 \\
\hline \multirow{2}{*}{52} & \multirow{2}{*}{ rs1335873 } & $A$ & 0.716 & 0.617 & 0.702 & 0.658 & 0.728 & 0.923 & 0.691 \\
\hline & & $\mathrm{T}$ & 0.284 & 0.383 & 0.298 & 0.342 & 0.272 & 0.077 & 0.309 \\
\hline \multirow{2}{*}{53} & \multirow{2}{*}{ rs1028528 } & $A$ & 0.555 & 0.589 & 0.550 & 0.688 & 0.709 & 0.232 & 0.742 \\
\hline & & G & 0.445 & 0.411 & 0.450 & 0.312 & 0.291 & 0.768 & 0.258 \\
\hline \multirow{2}{*}{54} & \multirow{2}{*}{ rs1528460 } & $A$ & 0.528 & 0.477 & 0.523 & 0.616 & 0.603 & 0.250 & 0.690 \\
\hline & & G & 0.472 & 0.523 & 0.477 & 0.384 & 0.397 & 0.750 & 0.310 \\
\hline
\end{tabular}

*Bold and italic number(s) represent minor allele frequency in three ethnics: the Malays, Chinese and Indians. 
Supplementary Table S2 Forensic parameters calculated for 52 SNPs for each Malaysian population group. MP (match probability); PD (power of discrimination); and PIC (polymorphisms information content).

\begin{tabular}{|c|c|c|c|c|c|c|c|c|c|c|c|}
\hline \multirow{2}{*}{$\begin{array}{l}\text { Marker } \\
\text { Code }\end{array}$} & \multirow{2}{*}{$\begin{array}{l}\text { SNP } \\
\text { (rs\#) }\end{array}$} & \multirow{2}{*}{$\begin{array}{l}\text { Allele } \\
(1 / 2)\end{array}$} & \multicolumn{3}{|c|}{ Malay } & \multicolumn{3}{|c|}{ Chinese } & \multicolumn{3}{|c|}{ Indian } \\
\hline & & & MP & PD & PIC & MP & PD & PIC & MP & PD & PIC \\
\hline 1 & rs1490413 & $\mathrm{T} / \mathrm{C}$ & 0.379 & 0.621 & 0.37 & 0.351 & 0.649 & 0.37 & 0.383 & 0.617 & 0.37 \\
\hline 2 & rs876724 & $\mathrm{C} / \mathrm{T}$ & 0.420 & 0.580 & 0.35 & 0.409 & 0.591 & 0.34 & 0.404 & 0.596 & 0.34 \\
\hline 3 & rs1357617 & $\mathrm{T} / \mathrm{A}$ & 0.567 & 0.433 & 0.23 & 0.543 & 0.457 & 0.25 & 0.474 & 0.526 & 0.32 \\
\hline 4 & rs2046361 & $\mathrm{T} / \mathrm{A}$ & 0.373 & 0.627 & 0.37 & 0.404 & 0.596 & 0.37 & 0.377 & 0.623 & 0.36 \\
\hline 5 & rs717302 & $A / G$ & 0.433 & 0.557 & 0.31 & 0.607 & 0.393 & 0.22 & 0.419 & 0.581 & 0.36 \\
\hline 6 & rs1029047 & $\mathrm{A} / \mathrm{T}$ & 0.397 & 0.603 & 0.35 & 0.431 & 0.569 & 0.33 & 0.357 & 0.643 & 0.37 \\
\hline 7 & rs917118 & $\mathrm{G} / \mathrm{A}$ & 0.485 & 0.515 & 0.29 & 0.457 & 0.543 & 0.32 & 0.419 & 0.581 & 0.37 \\
\hline 8 & rs763869 & $\mathrm{C} / \mathrm{T}$ & 0.355 & 0.645 & 0.37 & 0.373 & 0.627 & 0.37 & 0.501 & 0.499 & 0.28 \\
\hline 9 & rs1015250 & $\mathrm{G} / \mathrm{C}$ & 0.371 & 0.629 & 0.37 & 0.364 & 0.636 & 0.37 & 0.369 & 0.631 & 0.37 \\
\hline 10 & rs735155 & $\mathrm{T} / \mathrm{C}$ & 0.546 & 0.454 & 0.25 & 0.628 & 0.372 & 0.20 & 0.397 & 0.603 & 0.35 \\
\hline 11 & rs901398 & $\mathrm{C} / \mathrm{T}$ & 0.456 & 0.544 & 0.31 & 0.418 & 0.582 & 0.33 & 0.402 & 0.598 & 0.35 \\
\hline 12 & rs2107612 & $A / G$ & 0.442 & 0.558 & 0.33 & 0.467 & 0.533 & 0.31 & 0.563 & 0.437 & 0.38 \\
\hline 13 & rs1886510 & $\mathrm{G} / \mathrm{A}$ & 0.593 & 0.407 & 0.21 & 0.566 & 0.434 & 0.23 & 0.453 & 0.547 & 0.32 \\
\hline 14 & rs1454361 & $\mathrm{A} / \mathrm{T}$ & 0.369 & 0.631 & 0.37 & 0.409 & 0.591 & 0.37 & 0.383 & 0.617 & 0.36 \\
\hline 15 & rs2016276 & $\mathrm{T} / \mathrm{C}$ & 0.391 & 0.609 & 0.35 & 0.395 & 0.605 & 0.35 & 0.447 & 0.553 & 0.31 \\
\hline 16 & rs729172 & $T / G$ & 0.579 & 0.421 & 0.23 & 0.610 & 0.390 & 0.21 & 0.627 & 0.373 & 0.21 \\
\hline 17 & rs740910 & $A / G$ & 0.609 & 0.391 & 0.20 & 0.720 & 0.280 & 0.14 & 0.575 & 0.425 & 0.23 \\
\hline 18 & rs1493232 & $T / G$ & 0.408 & 0.592 & 0.36 & 0.417 & 0.583 & 0.36 & 0.378 & 0.622 & 0.36 \\
\hline 19 & rs719366 & $\mathrm{C} / \mathrm{T}$ & 0.423 & 0.577 & 0.35 & 0.496 & 0.504 & 0.28 & 0.416 & 0.584 & 0.34 \\
\hline 20 & rs1031825 & $T / G$ & 0.390 & 0.610 & 0.37 & 0.399 & 0.601 & 0.37 & 0.414 & 0.586 & 0.37 \\
\hline 21 & rs722098 & $A / G$ & 0.391 & 0.609 & 0.37 & 0.399 & 0.601 & 0.37 & 0.614 & 0.386 & 0.37 \\
\hline 22 & rs733164 & $A / G$ & 0.436 & 0.564 & 0.32 & 0.575 & 0.425 & 0.24 & 0.534 & 0.466 & 0.25 \\
\hline 23 & rs826472 & $\mathrm{G} / \mathrm{A}$ & 0.511 & 0.489 & 0.27 & 0.638 & 0.362 & 0.19 & 0.378 & 0.622 & 0.36 \\
\hline 24 & rs2831700 & $\mathrm{C} / \mathrm{T}$ & 0.379 & 0.621 & 0.37 & 0.402 & 0.598 & 0.37 & 0.486 & 0.514 & 0.29 \\
\hline 25 & rs873196 & $A / G$ & 0.580 & 0.420 & 0.23 & 0.717 & 0.283 & 0.15 & 0.528 & 0.472 & 0.26 \\
\hline 26 & rs1382387 & $\mathrm{G} / \mathrm{T}$ & 0.528 & 0.472 & 0.37 & 0.447 & 0.553 & 0.36 & 0.440 & 0.560 & 0.37 \\
\hline 27 & rs2111980 & $A / G$ & 0.411 & 0.589 & 0.36 & 0.378 & 0.622 & 0.36 & 0.398 & 0.602 & 0.37 \\
\hline 28 & rs2056277 & $A / G$ & 0.522 & 0.448 & 0.24 & 0.652 & 0.348 & 0.19 & 0.506 & 0.494 & 0.27 \\
\hline 29 & rs1024116 & $A / G$ & 0.706 & 0.294 & 0.16 & 0.733 & 0.267 & 0.14 & 0.426 & 0.574 & 0.32 \\
\hline 30 & rs727811 & $A / C$ & 0.386 & 0.614 & 0.37 & 0.403 & 0.597 & 0.35 & 0.459 & 0.541 & 0.34 \\
\hline 32 & rs1413212 & $\mathrm{C} / \mathrm{T}$ & 0.457 & 0.543 & 0.37 & 0.415 & 0.585 & 0.35 & 0.476 & 0.524 & 0.36 \\
\hline 33 & rs938283 & $\mathrm{C} / \mathrm{T}$ & 0.434 & 0.566 & 0.32 & 0.597 & 0.403 & 0.22 & 0.575 & 0.425 & 0.23 \\
\hline 34 & rs1979255 & $\mathrm{G} / \mathrm{C}$ & 0.354 & 0.646 & 0.37 & 0.370 & 0.630 & 0.37 & 0.381 & 0.619 & 0.36 \\
\hline 35 & rs1463729 & $A / G$ & 0.382 & 0.618 & 0.37 & 0.370 & 0.630 & 0.37 & 0.414 & 0.586 & 0.37 \\
\hline 36 & rs2076848 & $A / T$ & 0.470 & 0.530 & 0.31 & 0.420 & 0.580 & 0.34 & 0.550 & 0.450 & 0.37 \\
\hline 37 & rs1355366 & $\mathrm{C} / \mathrm{T}$ & 0.440 & 0.560 & 0.34 & 0.560 & 0.440 & 0.24 & 0.388 & 0.612 & 0.37 \\
\hline 38 & rs907100 & $\mathrm{G} / \mathrm{C}$ & 0.336 & 0.664 & 0.37 & 0.349 & 0.651 & 0.37 & 0.343 & 0.647 & 0.37 \\
\hline 39 & rs354439 & $\mathrm{A} / \mathrm{T}$ & 0.365 & 0.635 & 0.37 & 0.400 & 0.600 & 0.37 & 0.366 & 0.634 & 0.37 \\
\hline 40 & rs2040411 & $A / G$ & 0.414 & 0.586 & 0.34 & 0.401 & 0.599 & 0.35 & 0.412 & 0.588 & 0.37 \\
\hline 41 & rs737681 & $\mathrm{C} / \mathrm{T}$ & 0.560 & 0.440 & 0.24 & 0.609 & 0.391 & 0.21 & 0.367 & 0.633 & 0.36 \\
\hline 42 & rs2830795 & $A / G$ & 0.398 & 0.602 & 0.36 & 0.434 & 0.566 & 0.37 & 0.436 & 0.564 & 0.33 \\
\hline 43 & rs251934 & $A / G$ & 0.625 & 0.375 & 0.20 & 0.666 & 0.334 & 0.18 & 0.428 & 0.572 & 0.34 \\
\hline 44 & rs914165 & $\mathrm{C} / \mathrm{T}$ & 0.419 & 0.581 & 0.33 & 0.384 & 0.616 & 0.35 & 0.369 & 0.631 & 0.37 \\
\hline 45 & rs10495407 & $\mathrm{C} / \mathrm{T}$ & 0.433 & 0.567 & 0.32 & 0.422 & 0.578 & 0.33 & 0.571 & 0.429 & 0.23 \\
\hline 46 & rs1360288 & $A / G$ & 0.490 & 0.510 & 0.28 & 0.524 & 0.476 & 0.35 & 0.417 & 0.583 & 0.37 \\
\hline 48 & rs964681 & $\mathrm{C} / \mathrm{T}$ & 0.408 & 0.592 & 0.35 & 0.432 & 0.568 & 0.35 & 0.377 & 0.623 & 0.37 \\
\hline 49 & rs1005533 & $A / G$ & 0.517 & 0.483 & 0.27 & 0.442 & 0.558 & 0.33 & 0.432 & 0.568 & 0.35 \\
\hline 50 & rs8037429 & $A / G$ & 0.394 & 0.606 & 0.37 & 0.443 & 0.557 & 0.36 & 0.372 & 0.628 & 0.36 \\
\hline 51 & rs891700 & $A / G$ & 0.379 & 0.621 & 0.37 & 0.351 & 0.649 & 0.37 & 0.416 & 0.584 & 0.37 \\
\hline 52 & rs1335873 & $\mathrm{T} / \mathrm{A}$ & 0.443 & 0.557 & 0.32 & 0.405 & 0.595 & 0.36 & 0.418 & 0.582 & 0.33 \\
\hline
\end{tabular}




\begin{tabular}{|c|c|c|c|c|c|c|c|c|c|c|c|}
\hline 53 & rs1028528 & $A / G$ & 0.429 & 0.571 & 0.37 & 0.354 & 0.646 & 0.37 & 0.362 & 0.638 & 0.37 \\
\hline 54 & rs1528460 & $A / G$ & 0.389 & 0.611 & 0.37 & 0.666 & 0.334 & 0.37 & 0.553 & 0.467 & 0.37 \\
\hline & & & \multicolumn{3}{|c|}{$\begin{array}{l}\mathrm{MP}=1 \text { in } 3.9654 \mathrm{e}^{-19} \\
\mathrm{PD}>99.9999 \%\end{array}$} & \multicolumn{3}{|c|}{$\begin{array}{l}\mathrm{MP}=1 \text { in } 5.3964 \mathrm{e}^{-18} \\
\mathrm{PD}>99.9999 \%\end{array}$} & \multicolumn{3}{|c|}{$\begin{array}{l}M P=1 \text { in } 1.7459 e^{-19} \\
P D>99.9999 \%\end{array}$} \\
\hline
\end{tabular}


Supplementary Table S3 Observed (Obs.н) and expected (Exp.н) heterozygosities for 52 SNPs typed in 325 individuals from three Malaysian ethnic groups.

\begin{tabular}{|c|c|c|c|c|c|c|c|c|c|c|}
\hline \multirow{2}{*}{$\begin{array}{l}\text { Mark } \\
\text { er } \\
\text { Code }\end{array}$} & \multirow{2}{*}{$\begin{array}{l}\text { SNP } \\
\text { (rs\#) }\end{array}$} & \multicolumn{3}{|l|}{ Malay } & \multicolumn{3}{|c|}{ Chinese } & \multicolumn{3}{|l|}{ Indian } \\
\hline & & Obs.H & Exp.н & P-value & Obs.H & Exp.н & P-value & Obs.H & Exp.н & P-value \\
\hline 1 & rs1490413 & 0.50 & 0.50 & 1.00 & 0.41 & 0.49 & 0.12 & 0.51 & 0.50 & 0.85 \\
\hline 2 & rs876724 & 0.50 & 0.46 & 0.40 & 0.40 & 0.43 & 0.51 & 0.41 & 0.44 & 0.52 \\
\hline 3 & rs1357617 & 0.28 & 0.27 & 0.73 & 0.29 & 0.29 & 1.00 & 0.50 & 0.40 & 0.0166 \\
\hline 4 & rs2046361 & 0.50 & 0.50 & 1.00 & 0.54 & 0.50 & 0.43 & 0.44 & 0.48 & 0.54 \\
\hline 5 & rs717302 & 0.33 & 0.39 & 0.14 & 0.21 & 0.25 & 0.23 & 0.55 & 0.48 & 0.17 \\
\hline 6 & rs1029047 & 0.40 & 0.44 & 0.39 & 0.42 & 0.42 & 1.00 & 0.46 & 0.50 & 0.44 \\
\hline 7 & rs917118 & 0.32 & 0.35 & 0.41 & 0.48 & 0.41 & 0.10 & 0.55 & 0.49 & 0.23 \\
\hline 8 & rs763869 & 0.42 & 0.49 & 0.17 & 0.47 & 0.49 & 0.70 & 0.39 & 0.34 & 0.15 \\
\hline 9 & rs1015250 & 0.47 & 0.49 & 0.70 & 0.48 & 0.50 & 0.70 & 0.44 & 0.48 & 0.43 \\
\hline 10 & rs735155 & 0.28 & 0.30 & 0.35 & 0.23 & 0.22 & 1.00 & 0.42 & 0.45 & 0.53 \\
\hline 11 & rs901398 & 0.38 & 0.38 & 1.00 & 0.35 & 0.42 & 0.10 & 0.43 & 0.45 & 0.83 \\
\hline 12 & rs2107612 & 0.38 & 0.44 & 0.13 & 0.44 & 0.38 & 0.20 & 0.72 & 0.50 & $* 0.00000$ \\
\hline 13 & rs1886510 & 0.28 & 0.25 & 0.12 & 0.32 & 0.27 & 0.07 & 0.43 & 0.40 & 0.47 \\
\hline 14 & rs1454361 & 0.47 & 0.49 & 0.70 & 0.54 & 0.49 & 0.33 & 0.46 & 0.48 & 0.84 \\
\hline 15 & rs2016276 & 0.42 & 0.46 & 0.53 & 0.44 & 0.46 & 0.68 & 0.31 & 0.38 & 0.08 \\
\hline 16 & rs729172 & 0.25 & 0.26 & 0.72 & 0.22 & 0.24 & 0.43 & 0.17 & 0.23 & 0.0171 \\
\hline 17 & rs740910 & 0.27 & 0.23 & 0.21 & 0.17 & 0.16 & 1.00 & 0.25 & 0.27 & 0.47 \\
\hline 18 & rs1493232 & 0.52 & 0.48 & 0.43 & 0.51 & 0.47 & 0.40 & 0.44 & 0.48 & 0.43 \\
\hline 19 & rs719366 & 0.49 & 0.45 & 0.40 & 0.34 & 0.34 & 1.00 & 0.42 & 0.43 & 0.83 \\
\hline 20 & rs1031825 & 0.52 & 0.50 & 0.70 & 0.54 & 0.50 & 0.44 & 0.56 & 0.50 & 0.25 \\
\hline 21 & rs722098 & 0.49 & 0.49 & 1.00 & 0.54 & 0.50 & 0.44 & 0.76 & 0.50 & $* 0.00000$ \\
\hline 22 & rs733164 & 0.39 & 0.40 & 0.81 & 0.23 & 0.27 & 0.15 & 0.31 & 0.30 & 1.00 \\
\hline 23 & rs826472 & 0.35 & 0.32 & 0.56 & 0.22 & 0.21 & 1.00 & 0.45 & 0.48 & 0.55 \\
\hline 24 & rs2831700 & 0.49 & 0.49 & 1.00 & 0.54 & 0.50 & 0.44 & 0.35 & 0.35 & 1.00 \\
\hline 25 & rs873196 & 0.23 & 0.27 & 0.15 & 0.15 & 0.16 & 0.59 & 0.32 & 0.31 & 0.76 \\
\hline 26 & rs1382387 & 0.68 & 0.49 & $* 0.000$ & 0.58 & 0.48 & 0.05 & 0.58 & 0.49 & 0.05 \\
\hline 27 & rs2111980 & 0.52 & 0.48 & 0.42 & 0.46 & 0.48 & 0.69 & 0.54 & 0.50 & 0.45 \\
\hline 28 & rs2056277 & 0.32 & 0.28 & 0.30 & 0.19 & 0.21 & 0.18 & 0.34 & 0.33 & 1.00 \\
\hline 29 & rs1024116 & 0.16 & 0.17 & 0.25 & 0.15 & 0.15 & 1.00 & 0.33 & 0.41 & 0.05 \\
\hline 30 & rs727811 & 0.51 & 0.50 & 0.85 & 0.48 & 0.46 & 0.83 & 0.54 & 0.44 & 0.0194 \\
\hline 32 & rs1413212 & 0.61 & 0.49 & 0.0194 & 0.47 & 0.45 & 0.83 & 0.61 & 0.48 & 0.0025 \\
\hline 33 & rs938283 & 0.40 & 0.42 & 0.82 & 0.22 & 0.26 & 0.25 & 0.25 & 0.27 & 0.47 \\
\hline 34 & rs1979255 & 0.44 & 0.50 & 0.25 & 0.48 & 0.50 & 0.70 & 0.43 & 0.47 & 0.42 \\
\hline 35 & rs1463729 & 0.51 & 0.50 & 0.85 & 0.49 & 0.50 & 0.85 & 0.56 & 0.50 & 0.25 \\
\hline 36 & rs2076848 & 0.43 & 0.39 & 0.32 & 0.46 & 0.44 & 0.82 & 0.71 & 0.49 & $* 0.00000$ \\
\hline 37 & rs1355366 & 0.51 & 0.44 & 0.13 & 0.33 & 0.27 & 0.07 & 0.52 & 0.50 & 0.70 \\
\hline 38 & rs907100 & 0.35 & 0.50 & 0.0016 & 0.43 & 0.50 & 0.17 & 0.27 & 0.50 & $* 0.00000$ \\
\hline 39 & rs354439 & 0.43 & 0.49 & 0.32 & 0.52 & 0.49 & 0.55 & 0.46 & 0.49 & 0.56 \\
\hline 40 & rs2040411 & 0.45 & 0.45 & 1.00 & 0.42 & 0.45 & 0.66 & 0.56 & 0.50 & 0.25 \\
\hline 41 & rs737681 & 0.29 & 0.28 & 0.73 & 0.25 & 0.23 & 0.69 & 0.42 & 0.48 & 0.23 \\
\hline
\end{tabular}




\begin{tabular}{|c|c|c|c|c|c|c|c|c|c|c|}
\hline 42 & rs2830795 & 0.50 & 0.48 & 0.70 & 0.59 & 0.50 & 0.08 & 0.44 & 0.42 & 0.65 \\
\hline 43 & rs251934 & 0.21 & 0.23 & 0.40 & 0.19 & 0.20 & 0.62 & 0.46 & 0.43 & 0.66 \\
\hline 44 & rs914165 & 0.35 & 0.42 & 0.11 & 0.42 & 0.46 & 0.40 & 0.46 & 0.49 & 0.56 \\
\hline 45 & $\begin{array}{l}\text { rs1049540 } \\
7\end{array}$ & 0.39 & 0.41 & 0.64 & 0.42 & 0.42 & 1.00 & 0.31 & 0.26 & 0.07 \\
\hline 46 & rs1360288 & 0.33 & 0.35 & 0.78 & 0.65 & 0.46 & $\begin{array}{l}{ }^{*} 0.000 \\
00\end{array}$ & 0.57 & 0.50 & 0.18 \\
\hline 48 & rs964681 & 0.45 & 0.45 & 1.00 & 0.51 & 0.47 & 0.40 & 0.49 & 0.49 & 1.00 \\
\hline 49 & rs1005533 & 0.32 & 0.32 & 1.00 & 0.45 & 0.41 & 0.48 & 0.50 & 0.45 & 0.20 \\
\hline 50 & rs8037429 & 0.51 & 0.49 & 0.70 & 0.55 & 0.47 & 0.10 & 0.43 & 0.48 & 0.32 \\
\hline 51 & rs891700 & 0.50 & 0.50 & 1.00 & 0.43 & 0.50 & 0.17 & 0.54 & 0.49 & 0.32 \\
\hline 52 & rs1335873 & 0.44 & 0.41 & 0.49 & 0.50 & 0.47 & 0.55 & 0.38 & 0.42 & 0.36 \\
\hline 53 & rs1028528 & 0.58 & 0.50 & 0.12 & 0.39 & 0.49 & 0.0443 & 0.46 & 0.50 & 0.44 \\
\hline 54 & rs1528460 & 0.52 & 0.50 & 0.70 & 0.80 & 0.50 & $\begin{array}{l}{ }^{*} 0.000 \\
00\end{array}$ & 0.70 & 0.50 & $* 0.00000$ \\
\hline \multicolumn{2}{|c|}{ Mean } & 0.42 & 0.41 & & 0.41 & 0.40 & & 0.46 & 0.44 & \\
\hline \multicolumn{2}{|c|}{ s.d. } & 0.11 & 0.09 & & 0.14 & 0.12 & & 0.12 & 0.08 & \\
\hline
\end{tabular}


Supplementary Table S4 Results obtained from the analysis of 15 STRs and 52 SNPs with 51

casework samples.

\begin{tabular}{|c|c|c|c|c|}
\hline Case & Samples & In-house Labeled & 52 SNPS & Identifiler/Powerplex ${ }^{\odot}$ Sytem \\
\hline \multirow[t]{3}{*}{1} & Bloodstains on the pillow case & F1 & FP & FP \\
\hline & Bloodstains on the bedsheet & F2 & FP & PP-13 \\
\hline & Bloodstains on the blanket & F3 & FP & FP \\
\hline \multirow[t]{4}{*}{2} & Bloodstains on the mat & F4 & FP & FP \\
\hline & Bloodstains on the T-shirt & F5 & FP & FP \\
\hline & Bloodstains on the pair of jeans & F6 & FP & PP-7 \\
\hline & Bloodstains on the panties & F7 & FP & FP \\
\hline \multirow[t]{3}{*}{3} & Bloodstains on the blouse & F8 & FP & PP-8 \\
\hline & Bloodstains on the skirt & F9 & FP & FP \\
\hline & Bloodstains on the brassiere & F10 & FP & PP-8 \\
\hline \multirow[t]{2}{*}{4} & Bloodstains on the comforter 1 & F11 & FP & FP \\
\hline & Bloodstains on the comforter 2 & F12 & FP & FP \\
\hline \multirow[t]{6}{*}{5} & Bloodstains on the towel & F13 & PP-26 & PP-8 \\
\hline & Bloodstains on the pair of jeans & F14 & PP-39 & NP \\
\hline & Bloodstains on the blouse & F15 & NP & NP \\
\hline & Bloodstains on the camisole & F16 & FP & FP \\
\hline & Bloodstains on the skirt & F17 & FP & FP \\
\hline & Bloodstains on the sarong & F18 & FP & FP \\
\hline \multirow[t]{2}{*}{6} & Swab of the cable 1 & F19 & NP & NP \\
\hline & Swab of the cable 2 & $\mathrm{~F} 20$ & NP & NP \\
\hline \multirow[t]{10}{*}{7} & Bloodstains on the blanket 1 & $\mathrm{~F} 21$ & NP & NP \\
\hline & Bloodstains on the blanket 2 & F22 & FP & FP \\
\hline & Bloodstains on the shirt 1 & F23 & FP & NP \\
\hline & Bloodstains on the shirt 2 & F24 & FP & NP \\
\hline & Bloodstains on the shirt 3 & F25 & FP & NP \\
\hline & Bloodstains on the shirt 4 & F26 & FP & NP \\
\hline & Bloodstains on the shirt 5 & F27 & FP & PP-11 \\
\hline & Bloodstains on the shirt 6 & F28 & FP & PP-13 \\
\hline & Bloodstains on the shirt 7 & F29 & $\mathrm{FP}$ & FP \\
\hline & Bloodstains on the shirt 8 & F30 & FP & Weak/Inconclusive \\
\hline \multirow[t]{8}{*}{8} & Bloodstains on the plastic bag 1 & F31 & PP-50 & NP \\
\hline & Bloodstains on the shirt & F32 & PP-47 & NP \\
\hline & Bloodstains on the pair of jeans & F33 & FP & FP \\
\hline & Bloodstains on the towel & F34 & FP & FP \\
\hline & Bloodstains on the tissue paper & F35 & NP & NP \\
\hline & Bloodstains on the string 1 & F36 & FP & NP \\
\hline & Bloodstains on the string 2 & F37 & FP & NP \\
\hline & Bloodstains on the plastic bag 2 & F38 & NP & NP \\
\hline \multirow[t]{4}{*}{9} & Bloodstains on the pair of short pants & F39 & FP & PP-7 \\
\hline & Bloodstains on the T-shirt & F40 & NP & NP \\
\hline & Bloodstains on the underwear & F41 & PP-33 & PP-7 \\
\hline & Bloodstains on the baton & F42 & FP & FP \\
\hline \multirow[t]{9}{*}{10} & Bloodstains on the shirt 1 & F43 & FP & FP \\
\hline & Bloodstains on the shirt 2 & F44 & FP & FP \\
\hline & Bloodstains on the pairs of short pants & F45 & FP & FP \\
\hline & Bloodstains on the underwear & F46 & FP & NP \\
\hline & Bloodstains on the singlet & F47 & FP & NP \\
\hline & Bloodstains on the pair of short pants & F48 & FP & NP \\
\hline & Bloodstains on the panties & F49 & NP & NP \\
\hline & Bloodstains on the brassiere & F50 & NP & NP \\
\hline & Bloodstains on the slippers & F51 & NP & NP \\
\hline
\end{tabular}

Notes: FP- Full profile, PP- Partial profile and NP- No profile. 


\section{Supplementary Table 5 Statistical evaluation of SNP data using DNA.VIEW.}

\begin{tabular}{|c|c|c|c|c|c|c|}
\hline \multirow[t]{2}{*}{ Case } & \multirow[t]{2}{*}{ Samples } & \multirow{2}{*}{$\begin{array}{l}\text { In-house } \\
\text { Labeled }\end{array}$} & \multirow[t]{2}{*}{ Source of the samples } & \multirow[t]{2}{*}{52 SNPS } & \multicolumn{2}{|c|}{ Theta $(\theta)$} \\
\hline & & & & & 0.01 & 0.03 \\
\hline \multirow[t]{3}{*}{1} & Bloodstains on the pillow case & F1 & \multirow{3}{*}{ Samples are from the same source. } & FP & \multirow{3}{*}{$1 e^{-18}$} & \multirow{3}{*}{$720 e^{-15}$} \\
\hline & Bloodstains on the bedsheet & $\mathrm{F} 2$ & & FP & & \\
\hline & Bloodstains on the blanket & $\mathrm{F} 3$ & & FP & & \\
\hline \multirow[t]{4}{*}{2} & Bloodstains on the mat & F4 & \multirow[t]{4}{*}{ Samples are from the same source. } & FP & \multirow{4}{*}{$23 \mathrm{e}^{-18}$} & \multirow{4}{*}{$15 e^{-18}$} \\
\hline & Bloodstains on the T-shirt & F5 & & FP & & \\
\hline & Bloodstains on the pair of jeans & F6 & & FP & & \\
\hline & Bloodstains on the panties & F7 & & FP & & \\
\hline \multirow[t]{3}{*}{3} & Bloodstains on the blouse & F8 & \multirow[t]{3}{*}{ Samples are from the same source. } & FP & \multirow{3}{*}{$12 \mathrm{e}^{-18}$} & \multirow{3}{*}{$8.6 \mathrm{e}^{-18}$} \\
\hline & Bloodstains on the skirt & F9 & & FP & & \\
\hline & Bloodstains on the brassiere & F10 & & FP & & \\
\hline \multirow[t]{2}{*}{4} & Bloodstains on the comforter 1 & F11 & Samples are from the same source. & FP & & \\
\hline & Bloodstains on the comforter 2 & F12 & & FP & $2.7 \mathrm{e}^{-18}$ & $1.9 \mathrm{e}^{-18}$ \\
\hline 5 & Bloodstains on the towel & F13 & Samples are from the same source. & PP-26 & $1.7 \mathrm{e}^{-12}$ & $1.2 \mathrm{e}^{-12}$ \\
\hline & Bloodstains on the pair of jeans & F14 & & PP-39 & $17 \mathrm{e}^{-15}$ & $11 e^{-15}$ \\
\hline & Bloodstains on the blouse & F15 & & NP & & \\
\hline & Bloodstains on the camisole & F16 & Samples are from the same source. & FP & & \\
\hline & Bloodstains on the skirt & F17 & & FP & $3.2 \mathrm{e}^{-21}$ & $1.9 \mathrm{e}^{-21}$ \\
\hline & Bloodstains on the sarong & F18 & & FP & & \\
\hline 6 & Swab of the cable 1 & F19 & & NP & & \\
\hline & Swab of the cable 2 & $\mathrm{~F} 20$ & & NP & & \\
\hline 7 & Bloodstains on the blanket 1 & F21 & & NP & & \\
\hline & Bloodstains on the blanket 2 & F22 & Samples are from the same source. & FP & & \\
\hline & Bloodstains on the shirt 1 & F23 & & FP & & \\
\hline & Bloodstains on the shirt 2 & F24 & & FP & & \\
\hline & Bloodstains on the shirt 3 & F25 & & FP & & \\
\hline & Bloodstains on the shirt 4 & F26 & & FP & $200 e^{-21}$ & $110 e^{-21}$ \\
\hline & Bloodstains on the shirt 5 & F27 & & FP & & \\
\hline & Bloodstains on the shirt 6 & F28 & & FP & & \\
\hline & Bloodstains on the shirt 7 & F29 & & FP & & \\
\hline & Bloodstains on the shirt 8 & F30 & & FP & & \\
\hline 8 & Bloodstains on the plastic bag 1 & F31 & Samples are from the same source. & PP-50 & $41 \mathrm{e}^{-18}$ & $28 \mathrm{e}^{-18}$ \\
\hline & Bloodstains on the shirt & F32 & & PP-47 & $51 \mathrm{e}^{-18}$ & $30 e^{-18}$ \\
\hline & Bloodstains on the pair of jeans & F33 & & FP & $32 e^{-18}$ & $23 e^{-18}$ \\
\hline & Bloodstains on the towel & F34 & & FP & $32 \mathrm{e}^{-10}$ & $23 \mathrm{e}^{-10}$ \\
\hline & Bloodstains on the tissue paper & F35 & & NP & & \\
\hline & Bloodstains on the string 1 & F36 & Samples are from the same source. & FP & $320^{-18}$ & $230^{-18}$ \\
\hline & Bloodstains on the string 2 & F37 & & FP & $32 e^{-10}$ & $23 e^{-10}$ \\
\hline & Bloodstains on the plastic bag 2 & F38 & & NP & & \\
\hline 9 & Bloodstains on the pair of short pants & F39 & Samples are from the same source. & FP & $460 e^{-18}$ & $280 \mathrm{e}^{-18}$ \\
\hline & Bloodstains on the T-shirt & $\mathrm{F} 40$ & & NP & & \\
\hline & Bloodstains on the underwear & F41 & Samples are from the same source. & PP-33 & $28 \mathrm{e}^{-9}$ & $23 \mathrm{e}^{-9}$ \\
\hline & Bloodstains on the baton & F42 & & FP & $460 e^{-18}$ & $\underset{8}{280 e v^{1}}$ \\
\hline 10 & Bloodstains on the shirt 1 & F43 & & FP & & \\
\hline & Bloodstains on the shirt 2 & F44 & & FP & & \\
\hline & Bloodstains on the pairs of short pants & F45 & & FP & $570 e^{-18}$ & $360 e^{-18}$ \\
\hline & Bloodstains on the underwear & F46 & & FP & $5 / 0 e^{-10}$ & $360 e^{-10}$ \\
\hline & Bloodstains on the singlet & F47 & & FP & & \\
\hline & Bloodstains on the pair of short pants & F48 & & FP & & \\
\hline & Bloodstains on the panties & F49 & & NP & & \\
\hline & Bloodstains on the brassiere & F50 & & NP & & \\
\hline & Bloodstains on the slippers & F51 & & NP & & \\
\hline
\end{tabular}


Supplementary Table 6 Paternity cases evaluated using 15 STRs (PowerPlex 16) and 52 SNPs.

\begin{tabular}{|c|c|c|c|c|c|}
\hline \multirow[t]{2}{*}{ Case } & \multirow[t]{2}{*}{ Remarks } & \multicolumn{2}{|c|}{$\begin{array}{l}\text { Combined paternity index } \\
\text { (CPI) }\end{array}$} & \multicolumn{2}{|c|}{ Probability of paternity (\%) } \\
\hline & & 15 STRs & 52 SNPs & 15 STRs & 52 SNPs \\
\hline 1 & Trio & $1.09 e^{6}$ & $2.16 \mathrm{e}^{6}$ & 99.99991 & 99.99995 \\
\hline 2 & Duo & 179401 & 796.42 & 99.9994 & 99.9 \\
\hline 3 & Trio & $86.55 e^{6}$ & $7.55 e^{6}$ & 99.999999 & 99.99999 \\
\hline 4 & Trio & $43.41 e^{6}$ & $9.46 e^{6}$ & 99.999998 & 99.99999 \\
\hline 5 & Trio- 1 mutation & 87851 & $14.15 e^{6}$ & 99.999 & 99.999993 \\
\hline 6 & Trio & $11.407 e^{9}$ & $328.849 \mathrm{e}^{6}$ & 99.99999999 & 99.9999997 \\
\hline 7 & Duo & 108.978 & $5.14 \mathrm{e}^{6}$ & 99.09 & 99.99998 \\
\hline 8 & $\begin{array}{l}\text { Control 1-a family of } \\
5 \text { (father and } \\
\text { mother) with: } \\
\text { Child C } \\
\text { Child D } \\
\text { Child E } \\
\text { (2 mutations) }\end{array}$ & $\begin{array}{c}516.24 \mathrm{e}^{6} \\
27.72 \mathrm{e}^{6} \\
54.44\end{array}$ & $\begin{array}{c}3.96 \mathrm{e}^{6} \\
325.84 \mathrm{e}^{6} \\
3.26 \mathrm{e}^{6}\end{array}$ & $\begin{array}{c}99.9999998 \\
99.999996 \\
98.2\end{array}$ & $\begin{array}{c}99.99997 \\
99.9999997 \\
99.99997\end{array}$ \\
\hline 9 & Duo & 275561 & 77.32 & 99.9996 & 98.7 \\
\hline 10 & Duo & $5.24 e^{6}$ & 409.15 & 99.99998 & 99.8 \\
\hline 11 & Trio & $193.90 e^{6}$ & $17.43 e^{6}$ & 99.9999995 & 99.999994 \\
\hline
\end{tabular}

